\title{
An Examination of the Ability of Christian Schools to Prevent Deterioration of Doctrinal Integrity in Postmodern Christian Youth
}

David H. Bryant

Cedarville University

Follow this and additional works at: http://digitalcommons.cedarville.edu/education_theses

\section{Recommended Citation}

Bryant, David H., "An Examination of the Ability of Christian Schools to Prevent Deterioration of Doctrinal Integrity in Postmodern Christian Youth" (2006). Master of Education Research Theses. 13.

http://digitalcommons.cedarville.edu/education_theses/13 


\title{
AN EXAMINATION OF THE ABILITY OF CHRISTIAN
}

\section{SCHOOLS TO PREVENT DETERIORATION OF DOCTRINAL INTEGRITY IN POSTMODERN CHRISTIAN YOUTH}

\author{
A thesis submitted in partial fulfillment \\ of the requirements for the degree of \\ Masters of Education
}

By

DAVID HUGH BRYANT

B.A. Biology, University of California, San Diego, 1989

Teacher Certification, Christian Heritage College, 1990

2006

Cedarville University 
CEDARVILLE UNIVERSITY

SCHOOL OF GRADUATE STUDIES

August 21,2006

\section{HEREBY RECOMMEND THAT THE THESIS PREPARED UNDER MY} SUPERVISION BY David H. Bryant ENTITLED An Examination of the Ability of Christian Schools to Prevent Deterioration of Doctrinal Integrity in Postmodern Christian Youth BE ACCEPTED IN PARTIAL FULFILLMENT OF THE REQUIREMENTS FOR THE DEGREE OF Master of Education.
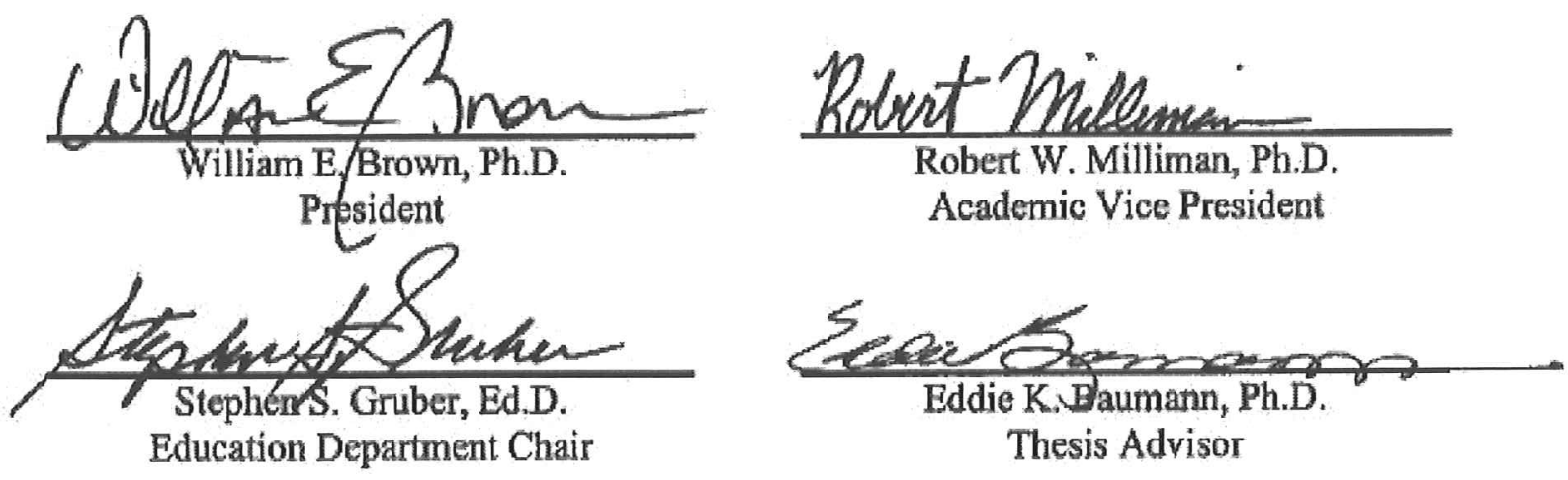


\begin{abstract}
Bryant, David H. M.Ed., Education Department, Cedarville University, 2006. An Examination of the Ability of Christian Schools to Prevent Deterioration of Doctrinal Integrity in Postmodern Christian Youth.
\end{abstract}

Can Christian schools prevent the deterioration of doctrinal integrity, or do factors such as the church and family have a greater impact? Sixty young adults were surveyed that had attended Christian school for four or more years during seventh through twelfth grades as were thirty-one that had not. The purpose was to assess the influence that Christian school, church, and family have had on the doctrinal integrity of eighteen to twenty-one year-old Christians. Upon completion of the study, it was found that there was not a statistically significant difference in the doctrinal integrity of the two groups of students. However, a statistically significant correlation was found between doctrinal integrity and both church involvement and family influence. It was also found that among those surveyed, the degree of doctrinal "confusion" was not nearly as severe as that which had been presented in other research. 


\section{TABLE OF CONTENTS}

\begin{tabular}{|c|c|}
\hline & Page \\
\hline LIST OF TABLES AND FIGURES & vii \\
\hline CHAPTER I-INTRODUCTION & 1 \\
\hline Educational Significance & 1 \\
\hline Purpose & 4 \\
\hline Methodology & 7 \\
\hline Biblical Integration & 10 \\
\hline Application to Current School & 11 \\
\hline Summary & 12 \\
\hline CHAPTER II-LITERATURE REVIEW & 13 \\
\hline Doctrinal Integrity Defined & 13 \\
\hline Importance of Sound Doctrine & 16 \\
\hline Worldview Defined & 18 \\
\hline Worldview Transforming Culture & 19 \\
\hline Culture Transforming Worldview & 22 \\
\hline Modernism Defined & 24 \\
\hline Modernism's Influence on the Christian Worldview & 26 \\
\hline From Modern to Postmodern & 31 \\
\hline Postmodernism Defined & 34 \\
\hline The Voices of Postmodernism & 35 \\
\hline
\end{tabular}


The Tenets of Postmodernism $\quad 39$

Postmodernism and the Christian Worldview-the Negatives 42

Truth and the Definition of "Christian" 43

Truth and the Judeo-Christian Ethic 45

Abandoning the Metanarrative $\quad 48$

Postmodernism and the Christian Worldview—the Positives 51

Return to True Faith

A Witness in Life, Not Words Alone 53

Hope for the Hopeless

Hunger for Community $\quad 56$

Postmodernism + Truth $=$ Good $\quad 58$

Christian Schools-A Commitment to Biblical Truth. 59

Into the Christian School Classroom 63

$\begin{array}{ll}\text { CHAPTER III-METHODOLOGY } & 65\end{array}$

Presentation of the Problems $\quad 65$

Presentation of the Hypotheses $\quad 66$

$\begin{array}{ll}\text { The Survey } & 68\end{array}$

$\begin{array}{ll}\text { The Participants } & 77\end{array}$

$\begin{array}{ll}\text { The Variables } & 75\end{array}$ 
$\begin{array}{ll}\text { CHAPTER IV-RESULTS } & 77\end{array}$

$\begin{array}{ll}\text { Doctrinal Responses } & 77\end{array}$

$\begin{array}{ll}\text { Research Question \#1 } & 79\end{array}$

Research Question \#2 82

$\begin{array}{ll}\text { Research Question \#3 } & 83\end{array}$

Research Question \#4 84

CHAPTER V-SUMMARY, CONCLUSIONS, AND
RECOMMENDATIONS

$\begin{array}{ll}\text { Summary } & 86\end{array}$

$\begin{array}{ll}\text { Conclusions } & 87\end{array}$

$\begin{array}{ll}\text { Recommendations } & 90\end{array}$

$\begin{array}{ll}\text { Appendices } & 94\end{array}$

$\begin{array}{ll}\text { Appendix A } & 94\end{array}$

$\begin{array}{ll}\text { Appendix B } & 98\end{array}$

$\begin{array}{ll}\text { References } & 104\end{array}$

$\begin{array}{ll}\text { Vita } & 112\end{array}$ 


\section{LIST OF TABLES AND FIGURES}

Page

Table 1: Doctrinal statements and their responses consistent with a conservative evangelical doctrine

Table 2: Age and gender distribution of survey participants

Table 3: Christian college or university attendance among survey participants

Table 4: A comparison of doctrinal responses-

$4+$ years of Christian education vs. <4 years of Christian education

Figure 1: Comparison of mean Doctrinal Integrity Index based on Christian school criteria

Figure 2: Comparison of frequency distributions of the Doctrinal Integrity Index based on Christian school criteria

Figure 3: Comparison of mean Doctrinal Integrity Index based on attending Christian college following high school graduation

Figure 4: Scatter-plot of the correlation between Doctrinal Integrity Index and Family Influence Factor

Figure 5: Scatter-plot of the correlation between Doctrinal Integrity Index and Church Involvement Factor

Figure 6: Scatter-plot of the correlation between Doctrinal Integrity Index and the total years of Christian school (K-12)

Table 5: Kruskal-Wallis H test Doctrinal Integrity Index rankings

Table 6: A Comparison of Doctrinal Responses for Selected Survey Questions-Barna's Research vs. This Research 


\section{Acknowledgements}

Upon the completion of this thesis, I owe much gratitude to the many people who have offered so much these past years as I have sought my Master's degree.

First and foremost, I want to thank God who not only gave me the undeserved gift of salvation, but who has also provided the means and strength through which this thesis and all other coursework has been completed.

To my wife, Elicia, and my son, Nathan, thank you for the love, support, and patience that you have given. Thank you for sacrificing time with me and encouraging me to persevere. You two help bring out the very best in me!

I wish to also thank Dayton Christian Schools and Cedarville University for the financial assistance that made achieving this goal possible. I specifically thank Jim Rakestraw, Lee Reno, Dr. Roy Lowrie Jr. and the other DC and XC administrators who have encouraged me along the way to seek self-improvement by pursuing higher education.

Special thanks also goes to Dayton Christian and Xenia Christian Bible teachers, Paul Pyle and Brent Howland, as well as, Pastors Mikal Kildal, Paul Alexander, and Nick Osbourne, all of whom assisted me in collecting my surveys.

I think of Christian brothers such as John Hunter and Rob Haye who encouraged me and held me accountable when I felt like giving up. Dr. Blair Cook who has been a source of encouragement and many leads in trying to get surveys completed.

I also thank colleagues too numerous to mention who I've interacted with, both in my Masters classes, as well as in my school, that have stretched me, given me fresh insights, and encouraged me to be a better teacher.

Finally, I want to thank Dr. Eddie Baumann, my thesis advisor, whose classes have always caused me to think and to wrestle with difficult issues and alternative viewpoints. He has also fueled my interest in worldviews and postmodernism. Likewise, my gratitude goes out to the other excellent professors whose teaching has made this Masters of Education an invaluable and worthwhile experience. 


\section{CHAPTER I: \\ INTRODUCTION}

\section{Educational Significance}

Within education, the processes of assessment and evaluation are critical components of pedagogy. Teachers are continually examining students for their level of comprehension and understanding - to assure that material is being learned and internalized. Likewise, assessment and evaluation must be directed inward, as teachers, schools, even the educational system as a whole examines its effectiveness.

Evaluating and improving the success of our nation's educational system has been a major topic of discussion and a source of marked conflict throughout much of its history. In recent years, Americans have responded to both real and perceived challenges posed by international competition. Sometimes this competition is driven out of fear, as in the establishment of the National Science Foundation following the launch of Sputnik in 1957. As Joel Spring (2001, p.358) explains, "the Cold War between the United States and the Soviet Union spawned demands for more academic courses in the schools and a greater emphasis on science and math as a means of winning the weapons race with the Soviet Union." More recently, concerns over economic competition have energized the perception of the need for change. Since the 1980s comparisons to academic achievement in Japan and Germany have caused alarm and driven reform. The United States became a Nation at Risk.

In addition, educational policy and reform has been driven by a wide variety of domestic issues. Social and economic tensions have been, and continue to be, a significant motivator. For example, "during the 1960s, when civil rights and poverty were national concerns, the Federal government made education part of the national 
campaign against poverty" (Spring, 2001, p.358). Today education and politics are interwoven as much as any other time in our nation's history. Educational policy is used to convince voters that a candidate has their best interests in mind. The current push is to raise standards, raise accountability, and raise equality of access to educational resources. The educational policy of President George W. Bush's administration centers on legislation entitled No Child Left Behind. The ultimate goal is higher academic performance for every child regardless of race or socioeconomic status (U.S. Dept. of Education, 2003). There is a push to 'raise the bar' of academic achievement throughout the United States.

Most would agree that a human being is much more than just a mind. Everyone has a physical body. Schools have physical education classes and sports programs to encourage the development of the physical body. There has been growing concern of late that, as a nation, too many of our young people are overweight and unfit. According to Secretary of Health and Human Services Tommy Thompson, "Too many of our children are sitting around, and their inactivity is leading to serious health problems such as overweight, obesity and diabetes. Our kids need to be kids and be active. We need to get our children away from PlayStation and onto the playground" (Thompson as cited in Hellmich, 2002). As a result, there have begun a wave of reactions to address this issue and thus 'raise the bar' of physical fitness for our young people. One such example is the federal government's launching of “a $\$ 190$ million national campaign to promote physical activity and other positive activities for 9- to 13-year-olds. It's called 'VERB: It's What You Do"” (Hellmich, 2002). 
As Christian school educators, we share these same concerns. As ministers to those created in the image of God, we are given great responsibility for the stewardship and development of the young people that we teach. We have a responsibility to encourage academic excellence. Throughout scripture the cultivating of the mind is encouraged as a means to better understanding the world around us. For example, in Proverbs 18:15, we find that "the mind of the prudent acquires knowledge, and the ear of the wise seeks knowledge." In fact, the diligent use and development of the mind is one way by which Christians are actually supposed to express their love to God (see Luke 10:27)." Christian educators must have the highest academic standards.

In addition, we learn in 1 Corinthians 6:19 that "your body is a temple of the Holy Spirit who is in you, whom you have from God, and that you are not your own." Accordingly, Christian educators have a responsibility to foster healthy physical lifestyles in their students. Healthy eating habits and physical activity should be modeled, taught, and encouraged to the highest standard of excellence.

However, humans are not just mental and physical beings, they are also spiritual beings. Increasingly, these spiritual needs can not be addressed within the public school classroom; however, they should be the area of greatest concern to the Christian educator. For example, the educational philosophy of Dayton Christian Schools states that, "the entire process of education is seen as a means used by the Holy Spirit to bring the student into fellowship with God, to help him become strong or mighty in the Spirit..." (Dayton Christian Schools Faculty / Staff Handbook, 2000, p.100-5). Dayton Christian is typical of many evangelical Christian schools in proclaiming this spiritual emphasis. Therefore, while the secular and Christian education is concerned about having the highest standards 
and 'raising the bar' for academic and physical education, the Christian educational community needs to ensure that we are evaluating ourselves as to the quality of our students' spiritual education and formation. We must look to see that we are continually pushing ourselves towards excellence. There needs to be active assessment and evaluation along with an open spirit to what we may discover. We may find that adjustments need to be made and reform may be necessary so that we may be purposeful and effective in reaching the spiritual goals that we embrace.

\section{Purpose}

In October of 2002, hundreds of Christian school educators sat in the Dayton [Ohio] Convention Center and listened to an opening address by Christian apologist, writer, and speaker, Josh McDowell. Many were challenged and inspired by the words that were shared, as he introduced the concepts presented in his most recent work, entitled Beyond Belief to Convictions. The text is a reaction to some recent findings in surveys of youth that were performed by George Barna and the Barna Research Group. The resulting observations are that students, even those from Christian homes or churches, are adopting distorted beliefs about God, embracing distorted beliefs about truth, and accepting distorted beliefs about reality (McDowell \& Hostetler, 2002).

McDowell and Hostetler (2002, p.14) point out that our culture and its pervading philosophies are at the root of these beliefs by young people. "The postmodern influence has had a profound effect on what our kids believe about God, truth, and reality." As a result, "it is not that our kids are rejecting Christianity as they know it - they have simply been influenced to redefine it according to their cultural setting. They are putting together their own religious canon in a smorgasbord style." This problem is not isolated 
to just Christian youth. Chuck Colson (2000, p.80) describes what he calls "Salad-Bar Christianity," where "with self-fulfillment as their standard, [Christians] pick and choose, as if at a salad bar, from any belief system that provides comfort or meaning." To make matters worse, "the problem is that 'salad-bar Christianity' often goes unchallenged by the larger Christian community." This picking and choosing from various belief systems results in the formation of what would be called a "worldview." A worldview is "a way of seeing or picturing the world and everything in it. It's a conceptual framework. It determines how we interpret our experience and it guides our actions-whether we are conscious of it or not" (Phillips and Okholm, 2001, p.22). As a Christian's worldview becomes twisted and influenced by outside forces, such as culture, there is a profound effect on doctrinal integrity. The result is the distortions of doctrine, truth, and reality observed in the studies of the Barna Research Group, such as those presented in the book Real Teens (cf. Barna, 2001). As educators in evangelical Christian schools, we are to be in a partnership with the Church in assisting students in the formation of an evangelical, biblical worldview. For Christian school educators, there is a need to produce students in which the evangelical doctrine is more than a belief, but is instead a conviction that will resist corruption. McDowell and Hostetler (2002, p.31) define this conviction as "being so thoroughly convinced that Christ and His Word are both objectively true and relationally meaningful that you act on your beliefs regardless of the consequences." In helping students develop these convictions, the major truths of scripture or evangelical doctrine will be firmly established in their hearts.

One of the greatest attacks that our culture mounts against the formation of a biblical worldview is the benchmark of postmodernity, the denial of absolute truth. In 
addressing postmodernism, Os Guiness $(2000$, pp.11, 12) observes that "Truth in any objective or absolute sense, truth that is independent of the mind of the knower, no longer exists. At best, truth is relative-it's all a matter of interpretation and it all depends on the perspective. At worst, truth is 'socially constructed'-merely a matter of human convention and a testament to the community that believes it and the power that established it." Colson and Pearcey (1999, p.23) further defines this key characteristic of postmodernism, explaining that, "Postmodernism rejects any notion of a universal, overarching truth and reduces all ideas to social constructions shaped by class, gender, and ethnicity." As the concept of absolute truth is eroded within our culture, the idea of absolute biblical truth, the biblical worldview, and doctrinal integrity are compromised.

This study seeks to assess the effectiveness of Christian schools, partnered with the Christian home and church, in developing within their students a purely biblical worldview that is then reflected in their doctrinal beliefs later in life. More specifically, the study seeks answers to the following questions:

1. Are young adults ages eighteen to twenty-one that have attended a Christian school for at least four years of grades seven through twelve more likely to express beliefs that are consistent with evangelical doctrine than their public school peers?

2. Does the family's spiritual condition during grades seven through twelve, as evidenced through a set of survey questions, influence the doctrinal integrity of the same young adults, which may positively or negatively effect the efforts of the Christian school?

3. Does the degree of a student's church involvement during grades seven through twelve, as evidenced through a set of survey questions, influence the doctrinal 
integrity of the same young adults, which may positively or negatively affect the efforts of the Christian school?

4. Is there a significant correlation between the number of years that a child has attended a Christian school (K-12) and their doctrinal integrity as a young adult?

\section{Methodology}

As an approach to answering these questions, young adults between the ages of eighteen and twenty-one were surveyed. A total of 91 usable surveys were collected. Surveys were deemed unusable if they were incomplete, or if the person surveyed had been home-schooled during the $7^{\text {th }}$ through $12^{\text {th }}$ grades. At the end of the 2004-2005 school year, the Bible teachers at both the Dayton Christian and Xenia Christian Schools administered the survey to the outgoing seniors in their Bible class that had reached the age of 18. A total of 63 usable surveys were collected. This provided the majority of the sample of students that had met the criteria of four or more years of grades seven through twelve in a Christian school, as well as a few that had not. Local churches, Campus Crusade, and Athletes in Action were contacted to achieve an adequate sample of subjects that do not have the Christian school experience. Assistance was received from only three local churches and an additional 28 surveys were collected. In all, 60 of those surveyed met the Christian school criteria and 31 did not. Due to survey limitations, a response of "other Christian school" can only be interpreted as schools that are not public, Catholic, non-Christian private, or home school. The assumption that will be made is that these schools are generally similar in regards to doctrine and overall mission to Dayton Christian Schools. The distinctive characteristic regarding absolute and 
biblical truth of a Dayton Christian-like Christian school will be addressed in chapter 2 of this study. None of the young adults surveyed had Catholic school, or non-Christian private school experience.

The survey that was administered examined different aspects of a young adult's spiritual life. Information was collected about their relationship with Christ. In order to be included in the study, the respondent must be a professing Christian. This was determined in a similar manner to that used by the Barna Research Group (Barna, 2001, p.122). They were asked, "Have you ever made a personal commitment to Jesus Christ that is still important in your life today?" An affirmative response to this question was followed by the selection of one of seven options for what they believe will happen to them when they die, and why. If they chose the option, "When I die I will go to heaven because I have confessed my sins and accepted Jesus Christ as my Savior," they will be considered a professing Christian and included in the study. All of the surveys that were collected met this criterion. Information was collected about their educational experience, as well as their church involvement, family spiritual life, and church attendance and involvement during grades seven through twelve. Most importantly, those surveyed responded to statements that serve as indicators of their doctrinal and theological beliefs. A table of these questions can be found on page 15 of this study.

Respondents were given the following instruction: "Often times, people that go to church know how they should answer questions about God and the Bible, but I want you to answer the following questions with how you truly believe in your heart. I am not looking for any right or wrong answers, but instead, I'm trying to gain insight on the honest beliefs of young adults." In addition, the survey was completed in a manner in 
which the participant's name and the church that they attend remain anonymous. There is no place on the survey for any personally identifying information other than "sex" and "age." The source of the data will be coded for tracking purposes only as XC for "Xenia Christian," DC for "Dayton Christian," CH for "Church." No more specific identifiers were used. The hope is that in maintaining the anonymity of all involved, the data that was collected will most accurately reflect the spiritual life of the sample. Since all of the participants were over the age of eighteen, they were instructed that their completion of the survey provided implicit permission for the use of their responses in a research project. The complete survey instrument is contained in Appendix A of this study. Survey data received was statistically analyzed. The responses to the statements involving doctrinal and theological beliefs were calculated for each participant into a Doctrinal Integrity Index (DII). This index assigns point values to the responses given to these doctrinal statements. The responses "strongly agree," "agree," "disagree," and "strongly disagree" will be given the point values of $3,2,1$, and 0 or $0,1,2$, and 3 respectively depending on the nature of the statement. Responses to a statement that are consistent with an evangelical Christian doctrine will be assigned the higher value and those inconsistent with evangelical Christian doctrine will be assigned the lower value. Statistical analysis was then performed to answer the questions that have been proposed in this research study. See Chapter 3 for the detailed research methodology and Chapter 4 for the analysis and results of the data. 


\section{Biblical Integration}

As previously stated, the purpose of this study is to a make an assessment of the effectiveness of Christian schools in challenging the worldview dynamics of our culture by preserving doctrinal integrity in students. Throughout scripture, the act of selfevaluation and reflection has been an important part of the growth process for God's people.

Sometimes the examination is meant to come from God. For example, in Psalm 26:2, David cries out to God, "Examine me, O Lord, and try me; Test my mind and my heart." In a later verse he explains the purpose for this when the request is made to "search me, O God, and know my heart; try me and know my anxious thoughts; and see if there be any hurtful way in me, and lead me in the everlasting way" (Psalm 139:23,24). David wanted God to do some assessment of his life. He wanted God to reveal to him any errors in his way, so that he could make adjustments and improvements.

There are also instances in scripture where evaluation is made by another person. After the tabernacle had been built, "Moses examined all the work and behold, they had done it; just as the Lord had commanded, this they had done. So Moses blessed them" (Exodus 39:43).

Self-evaluation is a critical part of personal growth. The prophet Jeremiah had the right idea when he said, "Let us examine and probe our ways, and let us return to the LORD” (Lamentations 3:40). The Apostle Paul gives repeated instruction that "a man must examine himself" (1 Corinthians 11:28a). Those in Corinth were commanded to "Test yourselves to see if you are in the faith; examine yourselves" (2 Corinthians 13:5a). Furthermore, Paul explained to the Galatians that "each one must examine his own work, 
and then he will have reason for boasting in regard to himself alone, and not in regard to another" (Galatians 6:4). Paul also told the Thessalonians, "examine everything carefully; hold fast to that which is good" (1 Thessalonians 5:21).

This biblical principle of self-evaluation is supported even in the secular realms of psychology. Within learning theory, the concept of metacognition has been found to be an important component in the learning process. "Metacognition refers to one's awareness of thinking and the self regulatory behavior that accompanies this awareness" (Driscoll, 2000, p.110). In other words, it is the act of consciously reflecting on your own learning process and making required adjustments. Gagné and Glaser (1987, p.75) point out that "In the course of learning and problem solving, representative kinds of regulatory performance include: knowing when or what one knows or does not know... and checking and monitoring the outcomes of one's solution or attempt to learn." Examining and evaluating oneself should result in an honest appraisal of where we are and where we need to go, what we need to keep and what we need to get rid of or modify.

\section{Application to Current School}

The biblical mandate for self-evaluation does not apply only to an individual's personal growth. The same scriptural concepts can be applied to a group, community, or society as a whole.

Dayton Christian Schools plays an important part in the study because a majority of the sample with Christian school experience will be from Dayton Christian Schools. As such, this research will provide a penetrating self-evaluation of how well Dayton 
Christian is doing at making God's Word more than just a collection of verses, stories, and facts.

Dayton Christian Schools are typical of many Christian schools throughout the United States. Founded in 1963 and one of the founding members of the Association of Christian Schools International, Dayton Christian School has been a model for a number of other Christian Schools. Bud Schindler, the first superintendent of Dayton Christian, has authored several books using the school as a model for other Christian schools.

Therefore, the results of this study should be of interest to Christian educators in similar Christian schools.

\section{Summary}

The desire of this study is to examine the Christian educational community, specifically Dayton Christian Schools, Inc.—a school system composed of educators whose purpose is to teach God's children through the filter of God's Word. Specifically, the hope is to recognize strengths and weaknesses in the process by which young people are assisted in developing a biblical worldview that will help them resist the forces of culture and thus prevent the deterioration of doctrinal truth. In doing so, perhaps it will be discovered that some changes in the handling of culture and worldview issues are needed to minister effectively to students so influenced by their postmodern culture. The overarching purpose and goal is self-evaluation and improvement. 


\section{CHAPTER II:}

\section{LITERATURE REVIEW}

\section{Doctrinal Integrity Defined}

According to Merriam Webster's Collegiate Dictionary (1995, p.342), "doctrine" is "a principle or position or the body of principles in a branch of knowledge or system of belief." In the Christian context, Nelson's New Illustrated Bible Dictionary defines doctrine as "a body of beliefs about God, humankind, Christ, the church, and other related concepts considered authoritative and thus worthy of acceptance by all members of the community of faith" (Youngblood, 1995, p.363). Within this definition, there is presented the concept of a set, specific body of beliefs that is common to the "community of faith" or all Christians.

Among Christians there seems to be considerable disagreement in doctrine. Most notably, issues such as baptism, the timing of the return of Christ, and the manifestation of spiritual gifts such as speaking in tongues seem to suggest that there can be no common Christian doctrine. However, in explaining the nature of biblical doctrine, Wayne Grudem (1999, p.21) delineates between two types of doctrine, major and minor. "A major doctrine is one that has a significant impact on our thinking about other doctrines or that have a significant impact on how we live the Christian life. A minor doctrine is one that has very little impact on how we think about other doctrines and very little impact on how we live the Christian life." It is these major doctrines such as the authority of the Bible, the Trinity, the deity of Christ, and justification by faith in which we seek to find a consistency within the body of Christ. For the purpose of this study, the assessment will focus on those aspects of major doctrine. 
The standard that is being applied to measure doctrinal integrity is from a "conservative evangelical tradition." This tradition is rooted in the existence of the God of the Bible and the inerrancy and absolute truth of scripture. "Evangelicals believe that God speaks today through his written Word, the Bible. They insist that the Bible must stand as the sole norm for all of life" (Phillips and Okholm, 2001, p.53). Evangelical Christianity holds that "all Scripture is inspired by God" (2 Timothy 3:16a). This is emphasized in the Greek where the term describing the origin of scripture is theopneustos or "God breathed." "Evangelicals confess plenary and verbal inspiration-the whole (plenary) is inspired, even the very words (verbal)" (Phillips and Okholm, 2001, p.55). Consequently, to the evangelical, the Bible represents absolute truth. Psalm 119:151 exclaims "You are near, O Lord, and all your commandments are truth." Likewise, in prayer (to God, the Father), Jesus declares "Your word is truth" (John 17:17b). John MacArthur (2002, p.19) clearly summarizes this evangelical position. "[Scripture] is objectively true-meaning it is true whether it speaks subjectively to any given individual or not; it is true regardless of how anyone feels about it; it is true for everyone universally and without exception; it is absolutely true." This evangelical stand on absolute truth is a key component of the conflict addressed further in this study.

Doctrinal integrity, as defined in this study, is an adherence to a specific set of these conservative evangelical beliefs that are consistent with Grudem's definition of major doctrine. Table 1 presents the thirty-three statements that are being used in this study and the response that is consistent with conservative evangelical doctrine. These survey statements are nearly identical to the ones used by the Barna Research Group in the book Real Teens (Barna, 2001, pp.127-130). Consequently, Josh McDowell and 
others considering the concept of the disintegration of doctrinal integrity and a biblical

worldview in postmodern youth have used nearly the same survey as the basis of their

conclusions.

TABLE 1: Doctrinal statements and their responses consistent with a conservative Evangelical doctrine

\begin{tabular}{|c|c|}
\hline Statement & Desired Response \\
\hline 1. The Bible is totally accurate in all of its teachings & Agreement \\
\hline 2. You, personally, have a responsibility to tell other people of your religious beliefs. & Agreement \\
\hline 3. Your religious faith is very important in your life. & Agreement \\
\hline 4. The devil, or Satan, is not a living being but is a symbol of evil. & Disagreement \\
\hline $\begin{array}{l}\text { 5. If a person is generally good, or does enough good things for others during his or her } \\
\text { life, he or she will earn a place in heaven. }\end{array}$ & Disagreement \\
\hline 6. When Jesus Christ lived on Earth, He committed sins, like other people. & Disagreement \\
\hline 7. Prayer can change what happens in life. & Agreement \\
\hline 8. Jesus Christ was a real person. & Agreement \\
\hline $\begin{array}{l}\text { 9. A person can lead a full and satisfying life even if he or she does not pursue spiritual } \\
\text { development or maturity. }\end{array}$ & Disagreement \\
\hline $\begin{array}{l}\text { 10. People who do not consciously accept Jesus Christ as their Savior will be } \\
\text { condemned to hell. }\end{array}$ & Agreement \\
\hline 11. Forgiveness of sins is only possible through faith in Jesus Christ. & Agreement \\
\hline 12. Angels exist and influence people's lives. & Agreement \\
\hline 13. The universe was originally created by God. & Agreement \\
\hline 14. All people will be judged by God after they die, regardless of their religious beliefs. & Agreement \\
\hline 15. Jesus Christ was born to a virgin. & Agreement \\
\hline 16. All of the miracles described in the Bible actually took place. & Agreement \\
\hline 17. The whole idea of $\sin$ is outdated. & Disagreement \\
\hline 18. All religious faiths teach equally valid truths. & Disagreement \\
\hline $\begin{array}{l}\text { 19. After death, people are reincarnated—that is, they return to Earth in another life } \\
\text { form. }\end{array}$ & Disagreement \\
\hline 20. The Holy Spirit is a symbol of God's presence or power but is not a living entity. & Disagreement \\
\hline 21. After He was crucified and died, Jesus Christ did not return to life physically. & Disagreement \\
\hline 22. Your religious beliefs actually change the way you behave. & Agreement \\
\hline $\begin{array}{l}\text { 23. God created humans, but } \mathrm{He} \text { is no longer personally involved in your life or } \\
\text { experiences. }\end{array}$ & Disagreement \\
\hline $\begin{array}{l}\text { 24. There are some crimes, sins, or other behaviors people do that are so terrible that } \\
\text { they cannot be forgiven by God. }\end{array}$ & Disagreement \\
\hline $\begin{array}{l}\text { 25. It doesn't matter what religious faith you associate with because they all believe the } \\
\text { same principles and truths. }\end{array}$ & Disagreement \\
\hline 26. Your religious beliefs are not likely to change in the future. & Agreement \\
\hline 27. The Christian faith is relevant to your life today. & Agreement \\
\hline 28. The Bible provides a clear and totally accurate description of moral truth. & Agreement \\
\hline $\begin{array}{l}\text { 29. What you do for other people is more important than what you believe about Jesus } \\
\text { Christ. }\end{array}$ & Disagreement \\
\hline 30. The Bible does not provide many practical standards for living in today's world. & Disagreement \\
\hline 31. Anyone who relies upon the Bible for moral guidance is foolish. & Disagreement \\
\hline $\begin{array}{l}\text { 32. God is the all-knowing and all-powerful perfect Creator of the universe who still } \\
\text { rules the world today. }\end{array}$ & Agreement \\
\hline 33. You feel it is important to be a member of a church. & Agreement \\
\hline
\end{tabular}




\section{Importance of Sound Doctrine}

Doctrinal integrity is only one ingredient of a biblical worldview, but it is a critical component in the formation and continuation of that worldview. Without doctrinal integrity, the Christian worldview disintegrates. MacArthur (2002, p.xi) voices his concern stating that "we need to emphasize, not downplay what makes Christianity unique. And in order to do that effectively, we need to have a better grasp of how worldly thought is threatening sound doctrine in the church. We must be able to point out just where the narrow way diverges from the broad way."

From the evangelical perspective, sound doctrine is essential in maintaining the Christian identity. "In the Christian worldview it is as important to be correct about the object in which you put your trust as it is to have that trust in the first place. And when these beliefs are put into verbal or written form we refer to them as doctrines or dogmas" (Phillips and Okholm, 2001, p.60). In other words, faith without a clear understanding of what that faith is grounded in isn't faith at all. Using the term "theology" as the study or application of doctrine, the same authors explain that "Theology... represents the basic work of every believer. It is necessary for interpreting Scripture, evaluating the contemporary world, and shaping our identity as Jesus Christ's disciples" (Phillips and Okholm, 2001, p.65). Sound doctrine is critical in the life and faith of the believer.

The Bible itself emphasizes the importance and role of sound doctrine. Paul taught that a clear knowledge of true doctrine is essential for Christian growth (maturity). "We are no longer to be children, tossed here and there by waves and carried about by every wind of doctrine, by the trickery of men, by craftiness in deceitful scheming; but speaking the truth in love, we are to grow up in all aspects into Him who is the head, 
even Christ" (Ephesians 4:14,15 [emphasis added]). Sound doctrine is "food" for spiritual growth and the Christian is to be "constantly nourished on the words of faith and of the sound doctrine which [they] have been [instructed to follow]" (1 Timothy 4:6).

Paul also explains that knowledge of doctrine is necessary for standing against those who desire to pervert it. He recognized that "If anyone advocates a different doctrine and does not agree with sound words, those of our Lord Jesus Christ, and with doctrine conforming to godliness, he is conceited and understands nothing; but he has a morbid interest in controversial questions and disputes about words" (1 Timothy 6:4a). Instead, the Christian is to "[hold] fast the faithful word which is in accordance with the teaching, so that he will be able to exhort in sound doctrine and refute those who contradict" (Titus 1:9).

Finally, Paul predicted the exact focus of this study. Referring to those that claim Christianity, he declared that "the time will come when they will not endure sound doctrine; but wanting to have their ears tickled, they will accumulate for themselves teachers in accordance to their own desires, and will turn away their ears from the truth and will turn aside to myths" (2 Timothy 4:3,4). Modern day theologians have recognized this turning away. For example MacArthur (2002, p.viii) explains that "some who call themselves evangelicals are openly insisting that faith alone in Jesus is not the only way to heaven...[some] are simply cowardly, embarrassed, or hesitant to affirm the exclusivity of the gospel in an era when inclusivity, pluralism, and tolerance are deemed supreme virtue by the secular world." Likewise, others have pointed at the corrosion of the Christian worldview and the influence of postmodernism, such as the prevalence of relativism, as being the root causes of this turning away. Phillips and Okholm (1995, 
p.10) point out that "everyone seems to be following her own rules. Diversity of values and beliefs has become a societal virtue, infecting every part of our lives and respecting no one creed or religion... The very idea of an objective and absolute truth is an archaism in pluralistic American society."

\section{Worldview Defined}

As previously mentioned, doctrinal integrity is just one critical component of what is referred to as the Christian or Biblical worldview. In order to understand the relationship between postmodernism and doctrinal integrity it is important to understand how the two interact. Postmodernism, which will be defined and discussed later and in greater depth "refers to an intellectual mood and an array of cultural expressions that call into question the ideals, principles, and values that lay at the heart of the modern mindset" (Grenz, 1996, p.12). In other words, the philosophy of our culture directly affects a person's belief system. Considering our previous definition of doctrine as "a body of beliefs about God, humankind, Christ, the church..." (Youngblood, 1995, p.363), we can see that the two concepts will interact within a person's individual worldview.

The concept of worldview is extraordinarily complex, encompassing beliefs, philosophy, perception of the world, and motivation of actions. In simplest terms, a worldview is described as "a set of beliefs about the most important issues in life." The same author further defines it as "a conceptual scheme by which we consciously or unconsciously place or fit everything we believe and by which we interpret and judge reality" (Nash, 1992, p.16). Another text defines worldview as "a way of seeing or picturing the world and everything in it. It's a conceptual framework. It determines how 
we interpret our experience and it guides our actions-whether we are conscious of it or not" (Phillips and Okholm, 2001, p.22). Colson and Pearcy (1999, p.477) further explain that "no worldview is merely a theoretical philosophy. It is intensely practical, affecting the way we live our lives, day in and day out, as well as the way we influence the world around us." Since a person's thoughts, philosophies, and actions are extensions of their worldview, understanding of worldview is foundational, and is value-laden. "The point is that absolute objectivity is a myth. Everyone has a worldview that determines their values and their behavior" (Brown, 2001, p.68).

\section{Worldview Transforming Culture}

A worldview's influence on culture suggests the probable solution for the very observations that form the basis of this research. If the contemporary culture has influenced doctrinal integrity (negatively impacting a biblical worldview), then the way to combat this influence would be to help Christians develop a biblical worldview that influences and changes culture. This is indeed the rally cry of many. Colson and Pearcy (1999, p.477) explain that "Christians who understand biblical truth and have the courage to live it out can indeed redeem a culture, or even create one." McManus (2001, pp.64, 65) implores the Church that "We are not to build monuments, but to join the movement... When the church becomes a movement and not a monastery, she becomes a place of transformation for the very culture from which we run in fear." This redeeming of culture is the very essence of the book The Transforming Vision: Shaping a Christian Worldview. Walsh and Middleton (1984, pp.18, 19), having examined various international cultures, recognized that "when we look at a culture, we are looking at the 
pieces of a puzzle. [family, government, schools, church, business, sports, transportation, eating, art, music] All of these cultural activities are pieces of the puzzle. The central element which brings the pieces of the puzzle together into a coherent whole is the world view that has the leading role in the life of the culture." A culture is defined by its dominant worldview.

Christianity and its biblical worldview have fallen terribly short in its influence of our contemporary American culture. One reason is that Christians have found it easier and more comfortable to go along with the secular flow. "Culture forming is our God ordained creaturely task. Unfortunately, Christians have been culture followers rather than culture formers" (Walsh and Middleton, 1984, p.97). Christians have become trapped in dualistic though and actions that effect the manner in which they respond to culture. "Sadly, many believers fail to understand that scripture is intended to be the basis for all of life. In the past centuries, the secular world asserted a dichotomy between science and religion, between fact and value, between objective knowledge and subjective feeling. As a result, Christians often think in terms of the same false dichotomy, allowing our belief system to be reduced to little more than private feelings and experience, completely divorced from objective facts" (Colson and Pearcy, 1999, p.14). Therefore, we witness people that are Christians in some circumstances, Sunday mornings for example. Contrarily, they act just like the rest of the world in other areas of their lives, perhaps in business dealings or in sexual or moral issues. Walsh and Middleton (1984, p.32) have explained this phenomenon in coining the term "spiritual schizophrenia." "All the different aspects of culture... arise out of and are directed by its worldview... are all part of one piece because they are all guided by the same spirit. If 
they are not, then we experience a kind of spiritual schizophrenia, in which part of the life is led by one spirit and another part by a different spirit. Such a condition can not go on indefinitely without causing problems." And indeed, this has been one of many causes of the Christian's ineffectiveness in influencing culture.

Another such cause is the Christians focus on issues and not on the gospel of grace. Brown (2001, p.83) raises the question, "Why are we [Christians] known for what we are against rather than what we are for?" There is the tendency to focus on issues that are interpreted as unbiblical such as homosexuality, abortion, pornography, euthanasia, etc. Many Christians have aligned themselves politically based on these issues and, as a result, Christianity becomes recognized as solely a political agenda, not as a relationship with a personal and loving Savior. People see angry Christians instead of the love of Jesus Christ. In order for Christians to redeem culture, there has to be a focus on the foundational basis of Christianity, Jesus Christ. Instead of focusing on issues (what we are against), Christians need to live lives that reflect (what we are for) Christ. "Thinking as Christians can not be separated from living as Christians. In today's postmodern culture, people are looking for reasons to believe. They are not looking for finely tuned syllogisms or compelling arguments; they are looking for authentic lives" (Brown, 2001, p.79).

McDowell is well known for his apologetic works such as Evidence that Demands $a$ Verdict, wherein his premise is being able to convince people of the reality of the Gospel through facts and reason. A major premise in his more current work, Beyond Belief to Convictions is that we no longer live in an "evidence that demands a verdict world." We need to move from a typical defense of Christianity to what he calls a 
"relational apologetic," where the truth of Christianity is also shown to be relationally meaningful (McDowell and Hostetler, 2002). The world needs to see and experience a Christian community that is characterized by authenticity. Christians (the biblical worldview) can indeed transform culture "by embracing God's truth, understanding the physical and moral order he has created, lovingly contending for the truth with our neighbors, then having the courage to live it out in every walk of life. Boldly and, yes, joyously" (Colson and Pearcy, 1999, p.487).

\section{Culture Transforming Worldview}

Unfortunately, instead of witnessing a great Christian transformation of culture, it is much easier to recognize the profound influence that culture has had on the formation of worldview. In fact, a person's individual worldview is a product of the many influences that the world in which they live exerts upon them. "A worldview is formed in us by what we read, watch, listen to, and have modeled for us. We acquire it through the peers with whom we associate, our parents, and our church. It is developed by the activities we engage in and the experiences we have. And most importantly, it is shaped by what we love—-by the focus of our soul's eye" (Phillips and Okholm, 2001, p.24). When Christians are immersed in a secular, godless culture, the symbols and messages of that culture tend to be the most powerful predictor of how they begin to see the world.

As a result, Christians have a tendency to do one of two things. First, instead of adopting a biblical worldview, they completely succumb to a secular way of seeing the world. These are people that are basically Christians by name or upbringing. They may have made a profession of faith at one time, but Christ is not the center of their lives. 
Moseley (2003, p.17), in his book Thinking Against the Grain, recalls a friend whose mother describes herself as a Christian, yet "her opinions about everything are shaped by the culture and not by the Bible." This is all too common, he continues, because people "do not expose themselves regularly to the ideas of the Bible, so the ideas of culture win by default."

Or, they become entrenched in the type of "salad-bar" Christianity that was mentioned in the introduction, where Christians pick and choose from a variety of worldviews and beliefs as they seek to find meaning in the world. Horell (2004, p.9) calls this "religious eclecticism" which he defines as "a drawing together of spiritual resources from various Christian denominations and a combining of Christianity with the insights and practices from other faith traditions." He goes on to describe a man that he calls "Jerry" who "while [he] attends mass at his parish, he is also involved in a Biblestudy group at an evangelical Lutheran church...practices yoga and Buddhist meditation ...claim[ing] that all of these things help him to connect to God and other people, and to remain personally centered." Admittedly, these are extreme examples that exceed McDowell's observation of doctrinal deterioration in young people, but they do reflect the direction that culture is driving the worldview of the society into which young people are being assimilated.

There has been a shift in the way that people connect with God. "In the past, education in faith often focused on learning the doctrines, prayers, and rituals that expressed a particular understanding of the world. Faith formations moved toward the embracing of a framework of meaning and value that was applicable to all life situations" (Horell, 2004, p.8). That is, the development of a Christian worldview was once the 
anticipated result of Christian conversion and discipleship. This has changed. The current cultural climate has "led many religious educators to focus less on Christian worldviews...[fostering a] sense that we must increasingly face new, unprecedented situations, and that the established truths of Christian worldviews are less and less helpful as guides for our lives and faith communities" (Horell, 2004, p.9). But why is this dramatic shift being observed? In order to understand how our culture has had such an effect on worldview formations, we need to further understand the "intellectual mood" and philosophy that has dominated contemporary culture-postmodernism.

\section{Modernism Defined}

Before we can fully understand postmodernism, it is important to understand its predecessor-modernism. Modernism is the philosophical movement whereby man, by his intellect, can arrive at an understanding of himself and his world, ultimately solving all of the world's problems. "It became the goal of the human intellectual quest to unlock the secrets of the universe in order to master nature for human benefit and create a better world. This quest led to the modernity characteristic of the twentieth century, which has sought to bring rational management to life in order to improve human existence through technology" (Grenz, 1996, p.3). The culture of modernism was the result of a breaking away from the anti-intellectualism of the middle ages. "Western civilization had reached a state of maturity which led it to call into question fundamental assumptions of the culture of medievalism - in particular, a reverence for tradition which was exaggerated,

giving its support to social and ecclesiastical systems of inherited power and privilege..." (Thornhill, 2000, p.7). In a 1794 essay entitled "An answer to the Question: What is 
Enlightenment?" Immanual Kant (1724-1804) describes the emerging culture of modernity as follows: "Enlightenment is man's emergence from his self-incurred immaturity. Immaturity is the inability to use one's own understanding without the guidance of another. The immaturity is self-incurred if its cause is not lack of understanding, but lack of resolution and courage to use it without the guidance of another. The motto of the enlightenment is therefore: Sapere aude (Dare to be wise)! Have the courage to use your own understanding" (Kant as cited in Thornhill, 2000, p.9)! Modernism was characterized by the push from blind acceptance to the self-deterministic power of reason.

According to Millard Erickson (2001, pp.73, 74), the major content of modernism can be summarized into five main concepts as follows:

"1) Knowledge is considered to be a good that is to be sought without restriction. Knowledge will provide the solutions to humanity's problems...

2) Objectivity is both desirable and possible...

3) Foundationalism is the model for knowledge...

4) The individual knower is the model of the knowing process. Each person must assess the truth for himself or herself, even though the truth is the same for everyone.

5) The structure of reality is rational...The same logical structure of the external world is also found in the human mind, thus enabling the human to know and organize that world." 


\section{Modernism's Influence on the Christian Worldview}

In examining the influence that postmodernism is having on doctrinal integrity within the Christian worldview, it is important to understand the influence that its predecessor has had on the same. Modernism has been no friend of Christianity. The rational thinking of this age of reason was quick to establish the irrationality of the supernatural. Limitations were placed on God and the Bible quickly during this time of the Enlightenment. In his work entitled the Age of Reason, one of America's founding fathers, Thomas Payne (1737-1809) (1794, p.6) declares "I believe in one God, and no more; and I hope for happiness beyond this life." However, he quickly qualifies this belief saying, "I do not believe in the creed professed by... any church that I know of. My own mind is my own church. All national institutions of churches... appear to me no other than human inventions, set up to terrify and enslave mankind, and monopolize power and profit." The phrase "My own mind is my own church" is a descriptive slogan for this early movement away from a biblical understanding of God. Deism became the religion of the age. "According to the deists, the orderliness of nature does, in fact, prove the existence of a deity, a rational mind that created the universe. This God is, however, no longer involved in the creation...Miracles, revelation, and supernatural doctrines such as the incarnation and redemption are excluded on principle. According to this religion, human beings, armed with reason, are basically on their own" (Veith, 1994, p.33). The deist's beliefs were rooted in the modern philosophies that place a focus on the rational nature of man.

There were many philosophers that were forces in the development of these modern views concerning the primacy of reason and empiricism. René Descartes (1596- 
1650), a French mathematician and philosopher, was foundational in the development of modernistic thinking. "Often referred to as the father of modern philosophy...He embodies many of the characteristics of the modern period intellectually, and in some ways does that so fully that he is the basis for some of the caricatures that have been offered regarding modern thinkers in general" (Erickson, 2001, p.53). Philosophically, he is most known for his statement cogito ergo sum (I think, therefore I am). Descartes postulated that the very act of reason established man's existence. "The point is that from the activity of doubting [or reason], Descartes infers the existence of himself as the subject" (Erickson, 2001, p.57). In his elevation of man's power to reason, however, he maintains the existence of God. His writings, for example, referred to "the all powerful God" and the "goodness of God" (Erickson, 2001, p.56).

Likewise, the philosopher, John Locke (1632-1704), maintained the existence of God. He is known for moving from rationalism, belief in the power of reason alone, to empiricism, belief that truth is revealed through experience. Unlike his predecessors, Locke did not believe that ideas were innate within the human mind, but they were instead discovered through our interaction with the world through the senses. "All our ideas, he contends, come from either sensation or reflection, which together he terms experience" (Erickson, 2001, p.63). Spiritually, "Locke was a strong believer in the voluntary nature of religion." He also believed that "since persons of various religions are equally sure of the truth of their position, it is likely that no one has all of the truth, and thus toleration is to be extended to all. He did not, however, believe that this tolerance should be extended to atheists, because, being atheists, they would not be bound by promises, oaths, and covenants. He believed in the divine inspiration of the Bible, but 
held that even such revelation must be tested by reason" (Erickson, 2001, p.65). Despite Locke's elevation of reason above revelation, he affirms his belief in God by expressing this intolerance to atheism. However, as the Enlightenment gathered momentum, it was not long until the foundation of God began to crumble altogether.

Over time, philosophers such as Immanuel Kant (1724-1804) and Friedrich Nietzche (1844-1900) eliminated God from the picture. Kant focused on man being the source of knowledge. "For Kant both the sensory and the logical elements are necessary for there to be knowledge... we cannot get outside of our categories to know the object of intuition in itself apart from the way our mind structures that knowledge" (Erickson, 2001, p.73). The power of the human mind to make sense of the world took the place of God. "Kant argued that the external world owes its very shape and structure to the organizing power of the human mind, which imposes order on the chaotic data of the senses. Some...took this to imply that the self, in effect, is the creator of the universe" (Veith, 1994, p.36). Furthermore, Nietzche, in the late 1800's declared that God was dead and that man had killed him. There was no longer a need for God; after all he was just the invention of man, a myth. The same mind that was able to create God was now able to replace superstition with objective rationality. Truth was no longer based on revelation or myth, but instead, it was a product of man. "Enlightenment thinkers emphasized the ability of humans to discover truth on their own, without the aid of divine revelation" (Moseley, 2003, p.45). Both Kant and Nietzsche's philosophies were actually the seeds of postmodernism. Stanley Grenz describes Nietzche as "the beginning of the end of modernism and the inauguration of the gestation period of postmodernity" (Grenz, 1996, p.83). 
Finally, modernism and the Enlightenment ethos led to widespread acceptance of the naturalistic worldview. Naturalism is the end result of modernism's methods of approaching reality, rationalism and empiricism. It is the worldview of humanism which completely eliminates God from reality. Naturalism has been referred to as "the major competition to the Christian worldview" (Nash, 1992, p.116). Naturalism grew out of a chasm between spiritual and physical knowledge. "The division between these two kinds of knowledge widened until spiritual knowledge came to be regarded as unreal or unknowable, while physical knowledge was considered real and discoverable by humans using the scientific method" (Moseley, 2003, p.45). Mosely (2003, p.46) sums up the major tenets of naturalism as "only nature exists (no God), nature has always existed (no creation), nature is uniform (no miracles), and nature is deterministic (no free will)". Carl Sagan epitomizes the naturalist position with the often quoted line from his book Cosmos_-"The Cosmos is all that is or ever was or ever will be" (Sagan, 1980, p.4).

As a result, naturalism gives way to the complete denial of God and selfsufficiency of man and his ability to reason—humanism. According to the Humanist Manifesto 2000, "The unique message of humanism on the current world scene is its commitment to scientific naturalism. [It] enables human beings to construct a coherent worldview disentangled from metaphysics or theology and based on the sciences" (Kurtz, 2000, p.24). Naturalism is celebrated by the humanists for its ability to replace the fables of religion with the power of man's reasoning and the scientific method. The Humanist Manifesto II proclaims, "We find insufficient evidence for belief in the existence of a supernatural; it is either meaningless or irrelevant to the question of the survival and 
fulfillment of the human race. As non-theists, we begin with humans not God, nature not deity" (Kurtz, 1973, p.16).

Modernism and its religion of humanism have had far reaching implications in the deterioration and perversion of the Christian worldview. The influential Christian philosopher, Francis Schaeffer (1981, p.24) points out that "the humanist world view...controls the consensus in society, much of the media, much of what is taught in our schools, and much of the arbitrary law being produced by the various departments of government." Because of this overwhelming role of secular humanism in society, some "Christian" theologians have made concessions in an effort to minister to the masses. Modernism influenced the Christian worldview by blending it with the secular humanist worldview. Schaeffer (1981, p.20), however, points out that this was a "death blow" to the Christian worldview because they "are two total concepts of reality standing in antithesis to each other." He goes on to explain the futility of this endeavor.

"There is no way to mix these two total world views. They are separate entities that cannot be synthesized. Yet we must say that Liberal theology the very essence of it from the beginning, is an attempt to mix the two. Liberal theology tried to bring forth a mixture soon after the Enlightenment and has tried to synthesize these two views right up to our own day. But in each case when the chips are down these liberal theologians have always come down, as naturally as a ship coming into home port, on the side of the nonreligious humanist. They do this with certainty because what their liberal theology really is is humanism expressed in theological terms instead of philosophic or other terms." 
In other words, in an attempt to accommodate modernist thought, the Christian worldview has made allowances and in so doing compromised God's word for the prevalent philosophies of the day.

Ultimately, however, modernism did leave intact the concept of truth. For those who chose to take a "leap of faith" or "irrationally" believe the Bible, Christianity remained a viable, personal decision. The modern evangelical Christian could study scripture and rationally adhere to the major doctrines of evangelical Christianity, deeming them as truth. Within modernity, a Christian worldview with its component of doctrine was possible, but with the shift into postmodernism, this concept of doctrinal truth has become less acceptable.

\section{From Modern to Postmodern}

Not every generation has the privilege of witnessing an incredible paradigm shift - the death of one dominant, overarching philosophy of life and the birth (or more accurately, the coming of age) of a new one. Those termed "Baby Busters," "Generation X," or even "the lost generation" have not only witnessed, but were participants and driving forces (consciously or unconsciously) in the transition.

This generation initially was characterized by the modernistic worldview and Enlightenment philosophies of the Baby Boomers. However, there was a steady transition away from modernism into postmodernism. Some speculate on its exact timing. For example, Thomas Oden (1992, p.32) suggests that the period of modernism "closed with such a precise moment of collapse (the literal fall of the vast symbolic concrete wall in Berlin)." However, many see this transition from modernism to 
postmodernism as a gradual process that even had its roots, as mentioned earlier, in the philosophies of Kant and Nietzche. Regardless of its exact timing, the transition has been steady and evident.

Modern ideology drove western culture into a condition where the intellect and human reason was honored above all else. It was in fact, the solution to all of society's problems. "In addition to assuming that knowledge is certain and objective, Enlightenment thinkers also assume that it is inherently good...The assumption of the inherent goodness of knowledge renders the Enlightenment outlook optimistic. It leads to the belief that progress is inevitable, that science, coupled with the power of education, will eventually free us from our vulnerability to nature, as well as from all social bondage" (Grenz, 1996, p.4). It was clear that man could solve all of his problems. This was echoed in the Humanist Manifesto II which points out that "humans are responsible for what we are or will become. No deity will save us; we must save ourselves" (Kurtz, 1973, p.16).

However, for many this type of reasoning came into question in the last half of the twentieth century. Can we save ourselves? Focus turned to the ills of society. Man's rationale seemed to create more problems than it solved-pollution, war, materialism, homelessness, and on and on. People began to realize that "the modern worldview constructs rationally designed systems in which human beings find it impossible to live" (Veith, 1994, p.39). There arose great discontent with the results of man's intellect. What had occurred was the "dehumanization" of man. During the 1960's, "many young people began questioning the fruits of modern civilization-technology, social regimentation, rational planning. They sought instead a way of life organically related to 
nature and free of moral and rational restraints" (Veith, 1994, p.40). The transition from modernism to postmodernism had been energized.

Grenz (1996, p.5) provides a powerful illustration of the shift from modernism to postmodernism using an analogy of the popular Star Trek television series. He points out that the original Star Trek was a reflection of the Enlightenment ideology.

"One hero of the old Star Trek was Spock. Although he was the only crew member that came from another planet (he was part human, part Vulcan), in his nonhumanness he actually served as a transcendent human ideal. Spock was the ideal Enlightenment man, completely rational and without emotion (or at least the ability to hold his emotions in check). His dispassionate rationality repeatedly provided the key to solving problems encountered by the crew of the Enterprise. In such cases, the writers appear to have been arguing that in the end our problems can be solved by the application of rational expertise."

Spock always struggled to keep the emotions from his human half under control, at times questioning the sense of that very humanness. This is held in great contrast to the characters in Star Trek: The Next Generation.

"In the next generation, Spock is replaced by Data, an android. In a sense, Data is a more fully realized version of the rational thinker than Spock, capable of superhuman intellectual feats. Nevertheless, despite his seemingly perfect intellect, he is not the transcendent human ideal that Spock embodies, because he is a machine. Unlike Spock, he desires not only to understand what it means to be human but in fact to become human. He believes he is somehow incomplete 
because he lacks such things as a sense of humor, emotion, and the ability to dream (and, indeed, he feels that he has become more complete when he later discovers that his maker programmed a capacity to dream into his circuitry)" (Grenz, 1996, p.9).

The use of reason and intellect is no longer the ultimate goal, or that which is most desirable. Instead, the expression of one's humanness assumes the foremost achievement. This exemplifies the very fuel of the transition from modernism to postmodernism—-the re-humanizing of culture.

\section{Postmodernism Defined}

The concept of postmodernism is difficult to define. As a starting point, most authors simply describe it as the period following modernity. For example, Oden (1992, p.43) comments that "postmodern consciousness is formally defined simply as that form of consciousness that necessarily must follow modernity... It is not a program but a succession." Grenz (1996, p.2) explains that "whatever else it might be, as the name suggests, postmodernism signifies the [movement] beyond modernism. Specifically, it involves the rejection of the modern mind-set, but launched under the conditions of modernity." When one begins to more closely examine the philosophies behind postmodernism and its implications, the definition of postmodernism becomes much more complex. Eagleton (1996, p.vii), for example, describes postmodernity as "a style of thought which is suspicious of classical notions of truth, reason, identity and objectivity, of the idea of universal progress or emancipation, of single frameworks, grand narratives or ultimate grounds of explanation. Against these Enlightenment norms, 
it sees the world as contingent, ungrounded, diverse, unstable, indeterminate, a set of disunified cultures or interpretations which breed a degree of skepticism about the objectivity of truth, history and norms, the givenness of natures and the coherence of identities." From this definition, it becomes quite obvious that a comprehensive handling of postmodernism would be well beyond the scope of this research. Therefore, for the purpose of this study, the major contributors to postmodern thought and the basic tenets of postmodernism will be briefly examined, and then the focus will be directed to several areas of postmodern consciousness that most influence the idea of doctrinal integrity.

\section{The Voices of Postmodernism}

There are many contributors to postmodern thought; however, there are three that are recognized as having a primary role in its development. According to Stanley Grenz (1996, p.123), "Many voices have joined the postmodern chorus. But of these, three loom as both central and paradigmatic — Michel Foucault, Jacques Derrida, and Richard Rorty. They constitute a trio of postmodern prophets..."

Michel Focault was a French philosopher and lecturer that lived a tragic life. During his college years, he is described as being "unsociable, unpopular, and unhappy, and even attempted suicide... [As a lecturer at the University of California, Berkeley], he was an active participant in the homosexual community in San Francisco" (Erickson, 2001, p.134). In 1984, at age 58, he was "cut down in the prime of life and at the peak of his influence by the scourge of the early postmodern era-AIDS" (Grenz, 1996, p.123). A major focus of Focault's work was the relationship between knowledge and power. He "contended that every interpretation is put forward by those in power and is thus an 
exercise of power...every assertion of knowledge is an act of power" (Erickson, 1998, p.86). "For Focault the truth is that which is established by those who have the power to do so... Those in power make sure that those with contrary ideas are not heard" (Erickson, 2002, p.47). "He argues that scholars have erroneously believed (1) that an objective body of knowledge exists and is waiting to be discovered, (2) that they actually possess such knowledge and that it is neutral or value-free, and (3) that the pursuit of knowledge benefits all humankind rather than just a specific class" (Grenz, 1996, p.131). Simply put, according to Focault, there can be no such thing as objective truth or knowledge because truth and knowledge is determined only by a small number of those that are in positions of power and for their benefit only. If one suggests that they possess the truth, that person is exerting their power on another. Focault addressed the ability of truth to change, in the belief that the "way to alter truth is not by intellectual argumentation or refutation, but by changing the political conditions that produce truth" (Erickson, 2001, p.149). This is in stark contrast to the modern belief of the human rationale being the driving force behind advances in truth and knowledge. Finally, as a result of his skepticism, Focault was opposed to the use of all-inclusive explanations or "metanarratives," claiming that "they have been used, historically, as a means of oppression, and they will continue to be so used" (Erickson, 2002, p.48). "Metanarrative is a term coined by postmodernists to refer to a grand narrative, or interpretation that has universal applications" (Moseley, 2003, p.62).

Like Focault, Jacques Derrida is also a French philosopher. His role in the postmodern movement is poignant even though his work is extremely difficult to understand. According to Erickson, the difficulty of understanding Derrida's thought and 
writing is legendary. Despite this difficulty, he is known as "the father of modern deconstruction...[,and] has also exerted a strong influence in the field of literary criticism" (Erickson, 2001, p.113). Deconstruction is the major force that drives Derrida's philosophy and analysis of reality. Deconstruction refers to the idea that meaning is a social construct. Moseley $(2003$, p.60, 61) explains that "postmodernists contend that language is a cultural creation and that language has no inherent meaning beyond what is socially constructed, and so, socially or politically determined." As a result, language can not have an objective absolute interpretation. "Language, therefore, does not reveal meaning as much as it constructs meaning... The status quo in each society expresses its power as it assigns meaning to language... Language is a tool of power and oppression [, therefore,] the goal of deconstruction is to undermine this power by taking apart the process of meaning-making" (Moseley, 2003, p.61). Deconstruction does not only attack the area of language, but is then applied to all areas of knowledge and reality. "Just as there is no inherent meaning in texts, which the reader attempts to discover and extract, so also reality as a whole does not contain an objective meaning... The meaning of reality is dependent on the knower, and each knower has a somewhat different perspective he or she brings to the knowing experience. There is no one meaning of the world, no transcendent center to reality as a whole" (Erickson, 1998, p.86). Like Focault, Derrida's deconstruction leads to the dismissal of the possible existence of a metanarrative to explain reality.

Richard Rorty, unlike Focault and Derrida, is an American intellectual. As a result, unlike the "continental European thinkers...[he] has traveled a different journey to the conclusions that he holds...includ[ing] the unique influence of American 
pragmatism" (Erickson, 2001, p.150). In fact, his conclusions are much like an extension of the John Dewey's pragmatism. Grenz (1996, p.154) comments that "Rorty is not merely repacking the older pragmatism. He gives a distinctly postmodern twist to the tradition pioneered by Dewey and others." Consistent with other postmodern thinkers, Rorty agrees that there is no objective truth, but rather than focusing on the issue of power, he takes a more pragmatic approach—Truth is what works. "Truth is not to be understood as an agreement with or correspondence of our ideas or language to the 'real world.' It is rather that which works, which enables us to cope with, or deal with, reality" (Erickson, 2001, p.166). From Rorty's perspective, pragmatism "focuses on action rather than contemplation. Pragmatists frame questions about what is 'right' in terms of what is 'useful.' They ask, 'what difference will this belief make to our conduct?' It is on these grounds that Rorty calls for an 'edifying philosophy"” (Rorty as cited in Grenz, 1996, p.154). As an alternative to seeking whether something is true, "a question of the relationship of such beliefs to Reality[,] what Rorty proposes instead is simply an explanation in terms of what has brought it about that the person believes this particular view" (Erickson, 2002, p.44). Like other postmoderns, Rorty recognizes the influence of culture as a determiner of truth and reality. "There is a contingency and a historical conditionedness to the understanding of the world, the self, language, and community. These are products of our community... Ethical values are not grounded on some metaphysical basis, but simply are the consensus of one's community" (Erickson, 2001, p.166). Like Derrida and Focault, Richard Rorty also rejects the idea of metanarratives, however not on the same basis. "He rejects metanarratives not so much for their adverse effects or the improper uses to which they have been put, but for the impossibility of a 
finite human being accomplishing such a feat" (Erickson, 2002, pp.49,50). Explaining his position, Rorty states, "I came to realize that the search of the philosophers for a grand scheme that would encompass everything was illusory. Only a theism that combined a God with equal measures of truth, love, and justice, could do the trick. But since I could not imagine myself being religious, and had indeed become more raucously secular, I did not consider that an option for me" (Rorty as cited in Erickson, 2002, p.49).

\section{The Tenets of Postmodernism}

Taking into account the beliefs of these and other postmodern thinkers, one can establish the major beliefs or tenets of postmodernism. They stand is stark contrast to modernism which further supports the view that postmodernism is in a sense a rebellion against modernistic thinking. Millard Erickson (1998, pp.18, 19) lists the major tenets of postmodernism as follows:

“1) The objectivity of knowledge is denied...

2) Knowledge is uncertain. Foundationalism, the idea that knowledge can be erected on some sort of bedrock of indubitable first principles, has had to be abandoned.

3) All-inclusive systems of explanation, whether metaphysical or historical are impossible, and the attempt to construct them should be abandoned.

4) The inherent goodness of knowledge is also questioned. The belief that by means of discovering the truths of nature it could be controlled and evil and ills overcome has been disproved by the destructive ends to which 
knowledge has been put (in warfare, for instance).

5) Thus, progress is rejected...

6) The model of the isolated individual knower as the ideal has been replaced by community-based knowledge. Truth is defined by and for the community, and all knowledge occurs within some community.

7) The scientific method as the epitomization of the objective method of inquiry is called into question. Truth is not simply known through reason, but through other channels, such as intuition."

Other authors have explained postmodernism directly by its contrast with modernism. For example Ihab Hassan contrasts the values of modernism and postmodernism with the following set of antitheses:

“1) Modernism emphasizes purpose and design; postmodernism emphasizes play and chance.

2) Modernism seeks a hierarchy; postmodernism cultivates anarchy.

3) Modernists value the type; postmodernists value the mutant.

4) Modernism pursues the underlying meaning of the universe expressed in language; postmodernism rejects both a discoverable meaning of the universe and 'meaning' in language” (Hassan as cited in Moseley, 2003, p.58).

Yet others describe postmodernism by the way that it is reflected in the behavior and characteristics of society. For example, Walter Truett Anderson (1990, pp.107, 108) lists "some of the givens of life in the early postmodern era," as follows: 
"1) The society itself is a social construction of reality. All of the things that identify and define a 'people'—-such as its boundaries, its culture, its political institutions — are the (usually reified) products of earlier inventions.

2) Individual identity is also a social construction of reality, and the concept of 'self' is different in different societies and in different stages of history.

3) We regard the collective beliefs of individuals (rather than the mind of God or the laws of history) as the ultimate repository of social reality (what is true is defined by what we all believe), and we know that beliefs can be modified.

4) Consequently, all sectors of society are deeply interested in finding out what people believe (public opinion) and modifying those beliefs (advertising, propaganda, brainwashing, public relations, and so forth).

5) In a postmodern society we perceive life as a drama, and our major issues involve the definition of personal roles and the fabrication of stories that give purpose and shape to social existence.

6) Public happenings have the quality of scenes created or stage-managed for public consumption. They are what Daniel Boorstin called pseudoevents."

There has indeed been a major paradigm shift in the pervasive philosophies of the world. In light of this, it is important to address how this shift has influenced the Christian worldview (including this idea of doctrinal integrity) and how the Church must 
respond to meet the challenges presented by postmodern thinking.

\section{Postmodernism and the Christian Worldview—-the Negatives}

As previously stated, modernism has been no "friend" of the Christian worldview. The question must then be addressed-Does postmodernism, in its stark contrast to modernism, offer some positive benefit or some hope to the Christian worldview? In addressing this question, we will first look at three elements of postmodernity that pose great alarm and danger to the Christian worldview-(1) truth and the definition of "Christian", (2) truth and the Judeo-Christian ethic, and (3) abandoning the metanarrative.

Quite possibly the most obvious conflict between postmodernism and the Christian worldview is the idea of truth. Evangelical Christianity maintains that the Bible, the Word of God, represents absolute truth. As previously mentioned, the Bible itself declares its truth with verses such as Psalm 119:151 that states "You are near, O Lord, and all your commandments are truth." Likewise, in prayer (to God, the Father), Jesus declares "Your word is truth" (John 17:17b). MacArthur (2002, p.19) clearly

summarizes the evangelical position. "[Scripture] is objectively true-meaning it is true whether it speaks subjectively to any given individual or not; it is true regardless of how anyone feels about it; it is true for everyone universally and without exception; it is absolutely true." Guiness (2000, p.78) concurs that "in the biblical view, truth is that which is ultimately, finally, and absolutely real, or the 'way it is,' and therefore is utterly trustworthy and dependable, being grounded in God's own reality and truthfulness." In the biblical worldview, Christianity and its resulting standards and beliefs are based on 
the absolute truth of God's word. Not so with postmodernism. "Postmodernism rejects any notion of a universal, overarching truth and reduces all ideas to social constructions shaped by class, gender, and ethnicity" (Colson and Pearcy, 1999, p.23). This has major implications both in the very definition of what it means to be a Christian as well as in the application of the Judeo-Christian ethic in society.

\section{Truth and the Definition of "Christian"}

What does it mean to be a Christian? Scripture tells us that Christians are saved by making a faith choice to accept the grace of God. According to Ephesians 2: 8-9, "For by grace you have been saved through faith; and that not of yourselves, it is the gift of God; not as a result of works, so that no one may boast." Scripture also makes it clear that salvation involves truth. 1 Timothy 2:4 describes a God "who desires all men to be saved and to come to the knowledge of the truth." One is considered a Christian by accepting the reality of biblical truth as found in the gospel. Postmodernism's approach to religion, however, is much different. For the postmodern thinker, religion generally, and Christianity in particular, is one choice among many. "Postmodernism assumes that there is no objective truth - that moral values are relative, and that reality is socially constructed by a host of diverse communities. These beliefs by no means rule out religion, as modernism tended to...Today religion is not seen as a set of beliefs about what is real and what is not. Rather religion is seen as a preference, a choice" (Veith, 1994, p.192). "In the postmodern world we are all required to make choices about our realities. You may select a life of experimentation, eternal shopping in the bazaar of culture and subculture. Or you may forgo the giddy diversity of contemporary life-style 
swapping and fall into step with some ancient heritage: be an Orthodox Jew or a fundamentalist Muslim or a Bible-toting Christian or a traditional Native American. The range of such choices is enormous, but the choice is still a choice and requires an entirely different social consciousness from that of the Jews, Muslims, Christians, and Native Americans who knew of no alternatives" (Anderson, 1990, pp.7, 8). In the postmodern world, Christianity is reduced to one choice among many equally valid choices. It is a choice based not on truth, but instead, preference. Guiness (2000, p.78) explains this transformation, suggesting that "whereas both the Bible and the best of Christian thinkers of Christian history invite seekers to put their faith in God because the message conveying that invitation is true, countless Christians today believe for other various reasons. For instance they believe faith is true 'because it works' (pragmatism), because they 'feel it is true in their experience' (subjectivism), because they sincerely believe it is 'true for them' (relativism), and so on." As a result, postmodernism transforms Christianity from an absolute truth that is true for everyone to an individual choice - what works for, feels right, or is true for that individual.

It is this altering view of truth that is perceived as the mechanism driving the deterioration of the biblical worldview in postmodern youth. According to McDowell and Hostetler (2002, p.12), "Our kids have been conditioned to believe that truth is not true for them until they choose to believe it." As a result, “today, merely 'believing' isn't enough. Not because believing isn't important; it is...In today's culture believing is made out to be more of a preference based on one's subjective feelings at the moment. And that kind of believing isn't enough" (McDowell and Hostetler, 2002, p.21). Instead of being driven by truth or fact, today's young people are being driven by feelings and 
experiences. George Barna (2001, p.43) explains that when we look at what determines reality for teens "we begin to realize that while family, friendships and personal achievement are important, experiences are what rule their lives. In a fast-paced, relativistic, information-drenched culture with fluid relationships and ever-changing faith views, the constant that keeps life meaningful and invigorating is the latest and most satisfying experience.” McDowell and Hostetler (2002, p.21) propose that what "Our kids [and all Christians] need [is] a deeply held belief in God and His Word, a belief that will ground them in the faith so that no matter what tests or trials or storms of life come their way, they will stand strong. We are talking about a belief that goes so deep that it unlocks the secrets to one's very own identity, purpose, and destiny in life."

\section{Truth and the Judeo-Christian Ethic}

Even apart from the salvation issue, the concept of truth holds great importance to the Christian. Os Guiness (2000, p.13) explains that "far from being a naïve and reactionary notion, truth is one of the simplest, most precious gifts without which we would not be able to handle reality or negotiate life. Neither unhealthy or repressive, truth is a vital requirement not only for individuals who would live a good life but for free societies that would remain free.” Beckwith and Koukl (1998, p.20) point out that “today we've lost the confidence that statements of fact can ever be anything more than just opinions; we no longer know that anything is certain beyond our subjective preferences. The word truth now means 'true for me' and nothing more." As a result, our culture has become plagued with moral relativity. 
Moral relativity is the idea that right and wrong is no longer based on an absolute, but instead is a personal or social construction. Grenz (1996, p.14) explains that "postmodern truth is relative to the community in which a person participates. And since there are many human communities, there are necessarily many different truths." This blurring of truth has done severe damage to the Judeo-Christian ethic in American culture. "When truth dies, all of its subspecies, such as ethics, perish with it. If truth can't be known, then the concept of moral truth becomes irrelevant" (Beckwith and Koukl, 1998, p.20). According to Francis Schaeffer, "If there is no absolute moral standard, then one cannot say in a final sense that anything is right or wrong...There must be an absolute if there are to be morals, and there must be an absolute if there are to be real values. If there is no absolute beyond man's ideas, then there is no final appeal to judge between individuals and groups whose moral judgment conflict. We are merely left with conflicting opinions" (Schaeffer as cited in McDowell and Hostetler, 1998, pp.55, 56). This is the observation of many evangelical cultural observers today. Biblical standards of morality (or the Judeo-Christian ethic) are now just opinions and those who seek to preserve them are labeled as "close-minded" or "intolerant." Issues such as abortion, euthanasia, and homosexuality are areas of intense conflict in a society where there is no longer right and wrong, just opinion.

Of even greater concern, however, is the blurring of moral Biblical truth within the Church itself. In a 1997 issue of World magazine, J.B. Cheaney writes that "before repairing the ruins of our society, Christians had better see to the crumbling walls of the church and reestablish the mandate we were given here... Our primary purpose is not to establish a moral society but to glorify God and pray that our faithfulness to Him will be 
reflected in our culture" (Cheaney as cited in McDowell and Hostetler, 1998, p.173).

This is a response to the observation that postmodernism's moral relativity has permeated the Church. Biblical guidelines for moral behavior have been overlooked or reinterpreted to satisfy the sin nature. Things that were once viewed as sin, when approached from scripture, are now acceptable in many "Christian" communities. Issues such as sexual promiscuity, cohabitation outside of marriage, and homosexuality are no longer limited to the realm of Church vs. Society, but are now great conflicts within the Church itself. "So rampant is [moral relativity] in the church today that biblical standards are being ignored-or redrawn—in favor of a more 'tolerant' approach...one that seeks to redefine marriage and sexuality according to human standards and 'sensibilities.'” (McDowell and Hostetler, 1998, p.182). Perhaps this blurring of morals within the Church has indeed, as Cheaney suggests, weakened the influence of the Church in our society.

Postmodernism's "death of truth" and the resulting relativism are having a grave influence on the Church and society. Beckwith and Koukl (1998, p.69) summarize the flaws of relativism as follows: "What kind of world [or Church] would it be if relativism were true? It would be a world in which nothing is wrong-nothing is considered evil or good, nothing worthy of praise or blame. It would be a world in which justice and fairness are meaningless concepts." Accordingly, "the genuine question facing postmodern culture is whether we can find norms to guide personal and societal development in a cultural context that has abandoned belief in moral standards as existing independently of particular human judgments and interests. How is it possible to live meaningfully if our ethical norms are simply constructions, not given to us by either God or nature" (Middleton and Walsh, 1995, p.58)? It is clear that the answer to this question 
is-it is not possible! As Christians seek to minister in a world that is dominated by postmodern thought, the tenet of the objectivity of truth is totally incompatible with the Christian worldview and must be rejected.

\section{Abandoning the Metanarrative}

In examining scripture, there is an apparent "big picture" that is revealed. It is a cohesive way to summarize all that is contained within the Bible and consequently to explain all that is observed in the world. The metanarrative of evangelical Christianity begins with creation, at which time all is perfect. There is no death, hurt, or pain. Man is in intimate fellowship with God. Then sin entered the world. The "fall of man" alienated mankind from God and brought all forms of destruction and sorrow into the world. The creation had been tainted and was no longer perfect. However, the promise of redemption was made - the time when all would once again be made perfect. All of this happens in the first three chapters of the Bible and the balance involves the quest for this promised redemption. God revealed to mankind what they should be looking for through various "types of Christ," until the promised Redeemer was revealed on a personal level through Jesus Christ. Now individuals can find redemption from sin as they wait for the time when all of creation will once again be made perfect. "The central element of reading scripture and the biblical message is the metanarrative that surrounds Jesus as the promised one who sends the Spirit to indwell and transform forgiven sinners who acknowledge their need for God's remedy...That metanarrative is something [Christians] 
embrace as true when [they] enter into communion and community with [Jesus]" (Bock, 2002, pp.30,31).

"Christians believe that there is one unifying story, a single history, including all peoples and all times" (Erickson, 1998, p.90). This all encompassing story is the Christian metanarrative. According to Moseley (2003, p.62), a "metanarrative is a term coined by postmodernists to refer to a grand narrative, or interpretation that has universal application...Such metanarratives serve as explanations of reality_of God, man, and the world. They are the philosophical foundations upon which we base our lives—our worldview." Grenz (1996, p.164) explains that "our world is more than a collection of incompatible and competing local narratives...the local narratives of the human communities do fit together into a single grand narrative, the story of humankind. There is a single metanarrative encompassing all peoples and all times...It is the story of God's action in history for the salvation of fallen humankind and the completion of God's intentions for creation." Erickson (2001, p.273) emphatically contends that "the biblical story constitutes the one genuine metanarrative...that the kingdom of God and all that is entailed in that concept is a comprehensive explanation of all that exists and occurs."

Postmodernism rejects the concept of the metanarrative- that there can be an all encompassing explanation for what we observe in mankind and the world. "To the postmodern mind, metanarratives are mere human constructs, fictive devices through which we impose an order on history and make it subject to us" (Middleton and Walsh, 1995, p.71). It is beyond the scope of this study to make a comprehensive examination of the reasons for this rejection, but Erickson (2002, p.103) sufficiently explains that "in various ways, the postmodernists decry metanarratives or all-inclusive philosophies. It 
may be simply because they cannot be constructed, or because they are constructed by the suppression of contrary voices, or simply that if adopted and practiced they have the effect of intolerance or being used oppressively. For whatever the reason, whether that they cannot be done or that they must not be done, postmodernism strongly opposes metanarratives."

Crucial to this discussion is to recognize that in midst of postmodernism; the Christian worldview vehemently opposes the rejection of the metanarrative. The rejection of the Christian metanarrative is a rejection of Scripture itself-a rejection of the Christian worldview. "The universal element in the Christian message, the claim that there is one God, one creator, one ruler of the human race, is so deeply embedded in the testimony of the biblical documents that it cannot be wrenched from Christianity without destroying the very organism" (Erickson, 2002, p.78). "Scripture must always have a central role in how the church thinks, in what the church believes and in forming who we are to be-the people of God. Without the Scripture we do not have the divine story. This story of the written Word is also where Truth ultimately resides for the Christian, in the One called the Word. It is why evangelicals in contending for the truth...must always bring its story back to him" (Bock, 2002, p.31). Christianity is not just a story, it is the story. "We simply cannot allow Christianity to be relegated to the status of one more faith among others... We believe not only that the biblical narrative makes sense for us, but is also good news for all. It provides the fulfillment of the longings and aspirations of all peoples. It embodies the truth—the truth of and for all humankind" (Grenz, 1996, p.165). 


\section{Postmodernism and the Christian Worldview-the Positives}

It is clear that postmodernism has implications and consequences for Christianity that are intolerable. However, some Christian thinkers maintain a position that there are aspects of postmodernism that are helpful, positive, and even influential in advancing the cause of Christ. It is useful to look to the strengths of postmodernism to address the problems that modernism has presented for evangelicals. Millard Erickson (2002, p.87) explains that "as with virtually any understanding of thought or life, postmodernism has both strengths and weaknesses. We need to appreciate and utilize the strengths, but with due recognition of its shortcomings."

There is a huge variation in evangelical Christianity's attitude toward postmodernism. For example, MacArthur (2002, p.12) states, "Christians cannot capitulate to postmodernism without sacrificing the very essence of our faith." He sees postmodernism as completely incompatible with Christianity and takes an isolationist viewpoint which he supports with James 4:4_-You adulterous people, don't you know that friendship with the world is hatred toward God? Anyone who chooses to be a friend of the world becomes an enemy of God." Because postmodernism involves a recognition of cultural influence (the world), Christianity and postmodernism are completely exclusive of one another. MacArthur recognizes only the negatives of postmodernism and dismisses any way that it can be used to further the Kingdom of God. He observes that "fewer and fewer Christians are willing to stand against the trends of this generation... [and feels that] the only cure...is a conscious wholesale rejection of postmodern values" (MacArthur, 2002, p.71). 
Carl Raschke takes a position opposed to McArthur's. In his book, The Next Reformation: Why Evangelicals Must Embrace Postmodernity, Raschke (2004, p.9) states that one of his purposes for writing the book is "to explore and suggest how embracing, rather than simply vilifying, the postmodern turn in Western thought widens the prospect for evangelical Christianity to flourish as a progressive rather than reactionary force in the present-day world." Likewise, Long (2004, p.83), in his book Emerging Hope, suggests that "to effectively minister in a postmodern culture, we first have to admit that we are in a new city and not waste time longing for our former city, the Enlightenment/modern era... if we continue to deny that we are moving into a new city, we will never be able to become settled or productive in it." "The church, in Grenz's estimation, has a mandate to listen to the voices within the academy and the culture to understand the culture in which it finds itself and to live out the gospel within that culture" (Erickson, 1998, p.92). There are many that agree that postmodern thought offers a new opportunity for evangelical Christianity.

\section{Return to True Faith}

One example of a positive aspect of postmodernism involves the very act of faith. Faith, a critical component of the Christian worldview, was greatly handicapped by the rationalism of the modern era. One could only have faith in something that could be seen or proven through empirical methodology. Postmodernism's tenet of deconstruction, in destroying truth, opens the door for faith. According to Raschke (2004, p.112), "Deconstruction is not faith per se, but it leaves a wide berth for faith. It is the trek into the desert so that faith can come into its own, so that there are no accessories to faith, so 
that faith can experience the pure presence of the One who is not present as an object at all." He further explains that "we respond to God in faith because we allow our systems of thought to be crucified and rejected, so that God may raise us up. There can be no faith without the preparation that the deconstructive power of the postmodernist discourse offers us" (Raschke, 2004, p.113). Likewise, Veith (1994, p.210) contends that "Christians can take advantage of the death of modernism to confess the historic Biblical faith to a lost and confused generation." Modernism kept man trapped in his "systems of thought," whereas postmodernism opens the door for faith. Raschke believes that postmodernism opens up the possibility of a return to the Reformation dictum of sola fide (by faith alone).

\section{A Witness in Life, Not Words Alone}

Second, the result of postmodernism is an emerging generation that is searching for truth in a much different way. Because of the dynamic of relativism brought on by postmodernism there is a rejection of truth and mistrust of authority. As a result, the act of knowing has shifted from rational thought to feeling and experience. This has previously been stated as a negative, but in light of the postmodern mood may also have a positive aspect. Long (2004, p.47) explains that for postmodern generations, "truth is not so much stated as experienced." Furthermore, "these generations need to have truth lived out before them, not stated to them. Words, in and of themselves, mean little to them; image means everything." Rich Mullins was a living example and proponent of a postmodern perspective of Christianity called the Ragamuffin Ministry. It arose from a book entitled The Ragamuffin Gospel by Brennan Manning which focuses on the 
humanness of man and the incredible grace of God. Manning (1990, p.49) explains that "Jesus spent a disproportionate amount of time with people described in the gospels as: the poor, the blind, the lame, the lepers, the hungry, sinners, prostitutes, tax collectors, the persecuted, the downtrodden, the captives, those possessed by unclean spirits, all who labor and are heavy burdened, the rabble who know nothing of the law, the crowds, the little ones, the least, the last, and the lost sheep of the house of Israel. In short, Jesus hung out with ragamuffins." God came to seek and save the lost and He can be seen through the living out of Christianity by a lowly human race. Mullins said, "I am a Christian, not because someone explained the nuts and bolts of Christianity to me, but because there were people who were willing to be nuts and bolts. Through their obedience to the truth and not necessarily through their explanation of it, they held it together so that I could experience it and be compelled to obey" (Mullins as cited in Raschke, 2004, p.163). The postmodern generation is not motivated by fact and formula; instead it is driven by experience and relationship. As a result, "we will need to emphasize embodying the truth in our lives versus only talking about the truth with our words. The lives of Christians will become more important to seekers as evidence to use in deciding whether or not to follow Christ" (Long, 2004, p.84). The experience of a changed life is a powerful tool for the outreach of the Christian Church because Christianity is all about changed lives.

\section{Hope for the Hopeless}


Christianity also benefits from postmodernism in that the postmodern ethos has created an atmosphere of hopelessness. "Today's younger generations suffer from a sense of past abandonment as well as hopelessness about the future" (Long, 2004, p.134). According to the Center for Disease Control—National Center for Injury Prevention and Control, "Suicide is the third leading cause of death among young people ages 15 to 24 " (CDC, 2005). "Once accidents were the main cause of death for teenagers. Youth were active, fun-loving, and often tragically reckless. Now suicide tops the list. Hopelessness is not only epidemic, it is endemic in our culture, a part of every fiber of our postmodern society" (Brown, 2001, p.99). Postmodernism has caused a steady evaporation of joy and a negative outlook toward the future. According to Joseph Feeney (1997), "This is the essence of postmodernism: a sense of exhaustion, a loss of feeling and meaning, minimal expectations and hopes, and a desire to parody everything." He quotes one student as saying, "I have no passion. I have no spirit. I have no religion."

The benefit for the Christian Church is that we possess the cure for this hopelessness. The "Good News" of the Gospel is that it brings hope and healing. Feeney offers an interesting solution to this negative manifestation of postmodernism. In fact, he makes a proposal that is consistent with the premise of this research. "A Catholic and Jesuit college education, I believe, can have a major role in healing the postmodern worldview. As an intellectual experience, it can examine the different worldviews and clarify their underlying values and suppositions. As a humanistic education, it can probe what it means to be human and offer a coherent worldview that includes both meaning and the spiritual. As Christian and Catholic, it can offer a living God, redemption in Christ, a community of believers and hope for this world and in eternity" (Feeney, 1997). 
The Gospel of Jesus Christ is precisely that—a message of hope. "Hope is a special feature of the biblical worldview. If there is anything that must define us as Christians, it is that we are people of hope...True hope is inaccessible to a world without God" (Brown, 2001, p.103). The Church has an incredible responsibility in this age to provide a place of hope and healing. "People in the emerging culture are searching for something to guide them as they live in the present and look toward the future. We have a golden opportunity to proclaim God's hope... Biblical hope is not built on confidence, but it builds confidence because it is based on the character of God, not on human potential or human capacity" (Long, 2004, p.131).

\section{Hunger for Community}

Finally, the postmodern focus on community offers great opportunity for the Christian Church. Erickson (2001, p.201) explains that "there is value in the postmodern emphasis on community versus individuality." Postmoderns are hungry for community and belonging. The internet provides powerful examples of this active seeking of community. One example is the prevalence of chat rooms and bulletin boards where people seek "fellowship" with others that have common interests. A fairly recent phenomenon is that of "blogging," an online journal or diary that is placed on the internet for a public sharing of one's thoughts. Many "blogs" or web logs provide avenues of interaction between author and readers. Another example is the online auction, Ebay. They refer to all of their members as the "community," and they encourage interaction between members of the "community." What an opportunity the Church has as an entity that has the ultimate in community to offer. 
Christianity itself places a major focus on community. From the very beginning in Genesis 2:18, God proclaims, "It is not good for the man to be alone." Throughout scripture the benefit of community is clearly presented. In Ecclesiastes 4:9-12, Solomon explains that "two are better than one because they have a good return for their labor. For, if either of them falls, the one will lift up his companion. But woe to the one who falls when there is not another to lift him up. Furthermore if two lie down together they keep warm, but how can one be warm alone? And if one can overpower him who is alone, two can resist him. A cord of three strands is not quickly torn apart." In the New Testament, the ideal of community over individuality becomes even clearer. Paul explains in several of his epistles that God has given each man certain gifts and it is important for all to work together in community. "For just as we have many members in one body and all the members do not have the same function, so we, who are many, are one body in Christ, and individually members of one another" (Romans 12:4,5). He expands on this thought in his first letter to the Corinthians. "For the body is not one member, but many...If they were all one member, where would the body be?" (1 Corinthians $12: 14,19)$. It is clear from scripture that Christians were made to work and live together in community.

The church must provide the brightest example of community to a world that is starved for it. Robert Webber in his book Ancient-Future Faith states that "in a postmodern world the most effective witness to a world of disconnected people is the church that forms community and embodies the reality of the new society. People in a postmodern world are not persuaded to faith by reason as much as they are moved to faith by participation in God's earthly community" (Webber as cited in Long, 2004, p.203). 
Ed Stetzer comments that "Community is the lightning rod that attracts postmoderns to participation in the metanarrative" (Stetzer as cited in Long, 2004, p.209). Christians have a great opportunity to reach the lost by providing a safe and loving community to those who are desperately seeking fellowship and then to lead them into fellowship with God through Christ.

\section{Postmodernism + Truth $=$ Good}

Even among those who recognize the positive aspects of postmodernism and the opportunities that it affords for ministry, there is a consensus that there must be a strong adherence to biblical truth. According to Veith (1994, p.210), "The church can be postmodern without being postmodernist. Christians can take advantage of the death of modernism to confess the historic Biblical faith to a lost and confused generation. To be relevant to the postmodern era, the church must simply proclaim the truth of God's word, the validity of God's law, and the sufficiency of the gospel of Jesus Christ." "Our task is to be faithful to the Gospel—-to the fundamental, non-negotiable beliefs of the Christian faith...we must also know how to speak the claims of the Christian worldview to our own culture, and that means that we must be faithful and relevant" (Phillips and Okholm, 2001, p.42). Although the methods for sharing and presenting the truth of God's Word need to change, the Word itself remains unchanged. There exists a body of doctrine that cannot be compromised. "There is an unchanging and timeless quality to Christianity, which is at least partly doctrinal...it is clear that certain doctrines are permanent, are part of the Christian religion, and are of such an indispensable nature that if they are given up, Christianity itself is lost" (Erickson, 2001, p.306,307). 
The Church faces a monumental task of maintaining the integrity and truth of the Bible, while making it relevant to the postmodern world. McDowell and Hostetler (2002, pp.55, 56), state that "how we relate to moral and spiritual truth should no longer be thought of merely as a philosophical concept or abstract idea but rather how we relate to a person. Evidences for the truth of Christ's deity, his resurrection, and the reliability of Scripture should not be offered as simply an apologetic—giving a defense of what we hold to be true — but they should also underscore the relational meaning of those truths." As Christians, we need to recognize that we live in a culture that is looking for feeling and situations that are experientially stimulating, that struggles with hopelessness, and is starved for community. It is a culture that is open to faith, but a faith that must be relevant to their day-by-day existence. Most importantly, it must be a faith that is adamantly committed to the truth of God's Word.

\section{Christian Schools-A Commitment to Biblical Truth}

Glen Schultz (2002, p.26), in his book Kingdom Education: God's Plan for

Educating Future Generations quotes an unknown author as follows:

“In the 1950's, kids lost their INNOCENCE. They were liberated from their parents by well-paying jobs, cars, and lyrics in music that gave rise to a new term-the generation gap. In the 1960's, kids lost their AUTHORITY. It was the decade of protest—church, state, parents were all called into question and found wanting. Their authority was rejected, yet nothing ever replaced it. In the 1970's kids lost their LOVE. It was the decade of me-ism, dominated by hyphenated words beginning with 
self: self-image, self-esteem, self-assertion. It made for a lonely world.

Kids learned everything there was to know about sex but forgot everything there was to know about love, and no one had the nerve to tell them there was a difference. In the 1980's, kids lost their HOPE. Stripped of innocence, authority and love, and plagued by the horror of a nuclear nightmare, large and growing numbers of this generation stopped believing in the future."

Schultz (2002, p.26) then goes on to add, "In the 1990's, kids lost the MEANING OF TRUTH. It was a decade when our national leaders redefined truth to be merely that which was legally accurate. Public opinion polls defined moral truth while the church sat by quietly and watched." Schultz (2002, p.46) further suggests that in light of the postmodern world in which the Christian student dwells, they must be educated in a place where God's truth is maintained. "If we do not base our educational efforts on the reality of God, then there is no truth. If there is no truth." He continues by quoting Chuck Colson, "then intellectual pursuits and education become merely a process. Fads displace learning, the intellect withers, and we end up refining the analytical without knowing what is to be analyzed...With no objective standard to point to what is true or real, music echoes discord; art reflects nothingness; literature stutters into chaos" (Colson as cited in Schultz, 2002, p.46). Therefore, there should be a difference in schools that purpose to maintain the truth and in the student that they produce. There should be a recognizable distinction in the doctrinal integrity of children in Christian schools because Christian schools are committed to the truth of Scripture. 
One of the foundational purposes of the Christian school movement is to create educational institutions where the truth of the Bible is not only maintained, but interwoven into all of the subject matter. Dayton Christian Schools, Inc. was founded in 1963 and rapidly grew to become one of the largest Christian schools in the country. Its first Superintendent, Claude E. "Bud" Schindler, wrote several books and Dayton Christian became a model for a number of other Christian schools. In the book, Still Educating for Eternity: The Case for Christian Schools, Schindler and Pyle (1997, p.36) write, "A truly Christian school is first of all centered in the authority of the scriptures and the person of Jesus Christ. Every subject is shot through with an awareness of God's power and love." "I think of education," the authors continue, "as having three E's: exposure to truth, expression of truth, experience in truth" (Schindler and Pyle, 1997, p.71). They continue, "Students must first be exposed to the truth before they are able to express it to others. Then through life experience, the truth will be made real" (Schindler and Pyle, 1997, p.83). This commitment to truth is expressed in the very first sentence of Dayton Christian School's mission statement. "Dayton Christian Schools, Inc. recognizes that God, through His Word, the Bible, is the absolute authority and basis for all truth" (Dayton Christian Schools, 2005).

This focus on God's truth is not only a characteristic of Dayton Christian Schools. For example, the mission statement of Alma Heights Christian Academy in Pacifica, California states, "Education is the search for truth and all truth ultimately derives from God, especially through the Bible" (Alma Heights Christian Academy, 2005). That of Christian Unified Schools of San Diego, states that "Christian Unified Schools of San Diego...teaches students to think, learn, and live from a Biblical worldview by 
integrating God and His Word as the primary source of knowledge and Truth" (Christian Unified Schools of San Diego, 2003). These are just a few schools representative of the Christian school movement. They are reflections of the overall Christian, biblical philosophy of education. This is a philosophy centered on God's truth. According to Kenneth Gangel (2003, p.60), "Christian educators affirm that all truth is God's truth, by which they simply mean that all genuine truth can ultimately be traced back to God as its source...For all of us, God's revelation—personal (Christ), written (the Bible), natural (creation) —stands as the foundation for a theology of learning and therefore a theology of truth." This foundation of Christian education is echoed by Paul Kienel (1995, p.iv). "Christian school educators believe that the Bible is what it says it is—-the truth...The Bible is the also the standard for all academic subjects. If some portion of a textbook does not square with the Word of God, we simply say that the textbook is in error on that point and that the Bible is correct. Our students must see us affirming the authority of the Scriptures. We must demonstrate our belief that there is no higher truth than Biblical truth. This is a fundamental principle of Christian school education."

Glen Schultz (2002, p.46), in addressing the impact of one's concept of reality and truth, makes the following three statements:

“A person's concept of reality and truth determines his beliefs!

A person's beliefs shape his values!

A person's values drive his actions!"

These statements emphasize how important truth is to the outcome of the educational experience. There should therefore be a distinct difference in the product of a Christian 
school education, an education with a firm commitment to placing biblical truth at the forefront of all that is done.

\section{Into the Christian School Classroom}

As a teacher in a Christian school stands before their class, they face a group of students that are in some way affected by the postmodern influence of our culture.

Almost without exception, what students believe and how they look at life is influenced, in large part, by television, music, video games, and the internet. "The influence of the mass media upon the hearts and minds of America's youth cannot be overestimated. Teens spend an average of four to six hours per day interacting with the mass media in various forms" (Barna, 2001, p.26). According to a report by the Kaiser Family Foundation (1999) entitled, Kids \& Media @ the New Millennium, each day, children age 8 to 18 spend an average of 6 hours, 43 minutes using media of any type. Each week, children age 2 to 18 spend an average of 19 hours, 19 minutes watching television and 10 hours, 4 minutes listening to music. 65 percent of children age 8 to 18 have a television in their room. Students face tremendous exposure to stimuli that is attempting to alter the way that they think about themselves and the culture in which they live. "Researchers contend that the typical American is exposed to more than 2000 commercial messages every day" (Barna, 2001, p.27). Media portrays materialism as success, it influences perceptions on issues such as sexuality, self-image, and moral relativism, and it begins to mold the watcher into what it portrays they should be. Actor Tim Reid observes, "I'm not sure black folks fully understand the power that media has in our life. We are becoming who they portray us as being. We've allowed ourselves to become a collection of negative 
statistics. Simon says dress like a gangster, and we do" (Tim Reid as cited by the Associated Press, 2003). The power of music in shaping the student's worldview cannot be ignored. "For millions of young people, music produces a life philosophy for them to consider and follow; cultural heroes to look up to and imitate; values and lifestyles to embrace; a common language to employ that sets them apart and provides a distinctive identity; and the opportunity to develop community related to a shared sense of common sound, ideas or artists" (Barna, 2001, p.27). Students are surrounded by cultural pressures to shape who they are and how they think.

In the meantime, the Christian educator is trying to influence their students to adopt a thoroughly Christian worldview. As a result, there exists a constant tension between the biblical truths that the teacher is attempting to transform into lifelong convictions in the hearts of their students and cultural postmodernism. The questions need to be asked. Are Christian educators being successful at influencing the "doctrinal integrity" of their students? Are they taking advantage of the opportunities that postmodernism presents while minimizing the negative influences of postmodernism? Are Christian educators teaching their students to effectively engage their culture from a biblical perspective? The shocking nature of the statistics presented by the Barna Research Group (cf. Barna, 2001) and echoed by McDowell and Hostetler (cf. McDowell and Hostetler, 2002) compel further research. 


\section{CHAPTER III: METHODOLOGY}

\section{Presentation of the Problems}

This research has thus far explored the characteristics of the transition from modernism to postmodernism and the influence that this transition has had on American youth culture. In recent years, tremendous alarm has been sounded among the Christian community regarding the influence that this transition has had on the Christian faith. This concern is proclaimed by the volumes of texts that have been written regarding ministering to a postmodern generation. As a result, many churches and youth groups have responded, attempting to make Christianity more relevant to the postmodern communities that they serve. But what about Christian schools? Has the status quo been effective in achieving its goals? The purpose of this study is to assess the effectiveness of Christian schools in preventing deterioration of doctrinal integrity in postmodern youth. Along with this evaluation, the study also seeks to address the influence of two other critical factors in a Christian student's spiritual formation - the church, and the home. As a result, four research questions have been proposed.

1. Are young adults age eighteen to twenty-one that have attended a Christian school for at least four years of grades seven through twelve more likely to express beliefs that are consistent with evangelical doctrine than their public school peers?

2. Does the family's spiritual condition during grades seven through twelve, as evidenced through a set of survey questions, influence the doctrinal integrity of the same young adults, which may positively or negatively effect the efforts of the Christian school? 
3. Does the degree of a student's church involvement during grades seven through twelve, as evidenced through a set of survey questions, influence the doctrinal integrity of the same young adults, which may positively or negatively affect the efforts of the Christian school?

4. Is there a significant correlation between the number of years that a child has attended a Christian school (K-12) and their doctrinal integrity as a young adult?

\section{Presentation of the Hypotheses}

In order to determine if young adults ages eighteen to twenty-one that have attended a Christian school for at least four years of grades seven through twelve are more likely to express beliefs that are consistent with evangelical doctrine than their public school peers, the study applied the following null hypothesis:

$\mathrm{H}_{0}$ : There will be no statistically significant difference in the doctrinal integrity of the control group (Christian education criteria not met) and the experimental group (Christian education criteria met) when comparing the difference in the Doctrinal Integrity Index.

In approaching this survey question, it becomes necessary to consider the influence of attending a Christian college or university following graduation from high school.

The researcher therefore proposes this additional null hypothesis:

$\mathrm{H}_{0}$ : There will be no statistically significant difference in the doctrinal integrity of the control group (Christian education criteria not met, Christian college or university not attended) and the experimental group (Christian education criteria not met, Christian college or university attended) when comparing the difference in the Doctrinal Integrity Index. 
The study also sought to examine if the family's spiritual condition during grades seven through twelve improves the doctrinal integrity of the same young adults. In order to determine this, the following null hypothesis will be used:

$\mathrm{H}_{0}$ : There will be no statistically significant correlation between a participant's Family Influence Factor and their Doctrinal Integrity Index.

In addition, in order to determine if the degree of a student's church involvement during grades seven through twelve improves the doctrinal integrity of the same young adults, the following null hypothesis will be used:

$\mathrm{H}_{0}$ : There will be no statistically significant correlation between a participant's Church Involvement Factor and their Doctrinal Integrity Index.

Finally, to determine if there is a significant correlation between the number of years that a child has attended a Christian school (K-12) and their doctrinal integrity as a young adult, the following null hypothesis will be used:

$\mathrm{H}_{0}$ : There will be no statistically significant correlation between the number of years that a participant had attended Christian school (K-12) and their Doctrinal Integrity Index. 


\section{The Survey}

For the purpose of testing the proposed hypotheses, a survey was designed. That survey contains several different components that are important for the research. The complete survey is contained in Appendix A of this study.

First, those surveyed were made aware of the requirements for participating in the study. They were instructed that the survey was to be completed only by those that are age eighteen to twenty-one. The reason for this age restriction was to achieve an adequate sample of young adults that had completed high school, but yet limited the amount of time that they had been out of high school. They were also informed that by completing the survey, they acknowledged that they met the age requirement and that permission was granted for their responses to be used for educational research. They were then asked to read the following:

"Dear Participant:

I want to take a moment to first thank you for taking part in this survey.

The information that is collected will be critical in answering some important questions that I am researching. To do this, I need to gather some background information about the educational experiences of people age 18 to 21 , as well as some information about their beliefs and attitudes toward church and religion.

As you can see, there is no place on this survey for your name or the name of your church. This is completely anonymous, so you can answer the questions honestly and express what you truly believe in your heart.

Often times, people that go to church know how they should answer questions about God and the Bible, but I want you to answer the following questions with how you truly believe in your heart. I am not looking for any right or wrong answers, but instead, I'm trying to gain insight on the honest beliefs of young adults." 
The desire was to encourage the participants to feel comfortable and free to respond honestly and accurately to the questions that were to be posed.

Second, participants were asked to indicate their gender. This is not directly related to any research question, but was asked to assess if the results might be biased by an overwhelming majority of one particular gender. In addition, they were asked for their age as another means of confirming that they did indeed meet the age criteria for the survey.

Finally, respondents were asked to indicate which of the following types of schools that they attended during the grades of kindergarten through twelfth: public school, Catholic school, any campus of Dayton Christian including Xenia Christian, any other Christian school (not Catholic), non-Christian private school, or home school. This information was used to discern between two groups of young adults, (1) those that attended Christian school for four or more years during seventh to twelfth grade and (2) those that did not attend Christian school for four or more years during seventh to twelfth grade. It was also used to determine the total number of years that each respondent had attended Christian school from kindergarten to twelfth grade. As part of this section, participants were also asked which of the following best described their activity following high school: attended Christian college or university, attended non-Christian college or university, or directly entered the workplace without college or university experience. The assumption being that attending a Christian college or university could influence "doctrinal integrity" and should therefore be considered in the analysis of the data. 
The survey was intended to be taken by subjects who professed to be "Christians." This was determined in a similar manner to that used by the Barna Research Group (Barna, 2001, p.122). Participants were asked, "Have you ever made a personal commitment to Jesus Christ that is still important in your life today?" An affirmative response to this question was followed by the selection of one of seven options for what they believe will happen to them when they die, and why. If they chose the option, "When I die I will go to heaven because I have confessed my sins and accepted Jesus Christ as my Savior," they were considered a professing Christian and included in the study.

The remainder of the survey intended to measure three different characteristics about each respondent. (1) the level of their church involvement during grades seven through twelve (what is being called the Church Involvement Factor or CIF), (2) the spiritual influence of their families during grades seven through twelve (what is being called the Family Influence Factor or FIF), and (3) how well they adhere to a conservative evangelical doctrine (what is being called the Doctrinal Integrity Index or $D I I)$. It is important to note that whereas the survey utilized questions from Barna's research in order to calculate the Doctrinal Integrity Index, the other two factors were calculated using the following methodology designed specifically for this study. This was done because, although the Barna research does address family and church issues among teens, it does not provide a comprehensive method for measuring these specific factors in a manner that would be adequate for this study. 
The Church Involvement Factor is derived from the response to three questions regarding their church experience during the target grades (seven through twelve).

1) How often did you go to church? Their responses were scored as follows:

\begin{tabular}{|c|c|}
\hline Response & Points \\
\hline SELDOM & 0 \\
\hline 1 OR 2 TIMES A MONTH & 2 \\
\hline WEEKLY & 4 \\
\hline TWICE A WEEK OR MORE & 6 \\
\hline
\end{tabular}

2) How would you describe your participation in youth group? Their responses were scored as follows:

\begin{tabular}{|c|c|}
\hline Response & Points \\
\hline NEVER & 0 \\
\hline SELDOM & 2 \\
\hline 1OR TWO TIMES A MONTH & 4 \\
\hline WEEKLY & 6 \\
\hline
\end{tabular}

3) Respondents were asked to check during which of the following time periods they attended church at least twice a month: grades $\mathrm{K}$ to 6 , grades 7 to 8 , grades 9 to 12 , and the time since graduation. They were given two points for each response with the exception of the "time since graduation." That was disregarded as not all respondents had had a "time since graduation." There was a total of eighteen points possible and the Church Involvement Factor was calculated using the formula:

$$
C I F=(\text { total points awarded } \div 18) \times 100
$$

Next, the Family Influence Factor is derived from the responses to eight questions regarding their family life during the target grades. 
1) Who most influenced your going to church? Their responses were scored as follows:

\begin{tabular}{|c|c|}
\hline Response & Points \\
\hline PARENTS & 4 \\
\hline OTHER RELATIVES & 2 \\
\hline FRIENDS & 0 \\
\hline I WENT ON MY OWN & 0 \\
\hline
\end{tabular}

2) Which of the parents that you lived with during the time you were in grades seven through twelve attended church? Their responses were scored as follows:

\begin{tabular}{|c|c|}
\hline Response & Points \\
\hline BOTH & 4 \\
\hline ONE (single parent home) & 3 \\
\hline ONE (two parent home) & 2 \\
\hline NEITHER & 0 \\
\hline
\end{tabular}

3) If you checked one of the first three choices in the previous question, check the statement that best describes the level of their church attendance. Their responses were scored as follows:

\begin{tabular}{|c|c|}
\hline Response & Points \\
\hline NO RESPONSE & 0 \\
\hline SELDOM & 2 \\
\hline 1 OR 2 TIMES A MONTH & 4 \\
\hline WEEKLY & 6 \\
\hline MORE THAN WEEKLY & 8 \\
\hline
\end{tabular}

For the last five questions of this section, an affirmative ("YES") response was given two points and a negative ("NO") response was given zero points. Respondents were instructed that "for the next TWO questions, 'routinely' means 3 to 4 or more times a week." The last five questions of this section were:

(1) Did your family routinely do devotions together?

(2) Did your family routinely pray together? 
(3) Did one or more parent attend Sunday school?

(4) Did one or more parent participate in a church service or Bible study other than the regular church service?

(5) Did one or more parent actively serve (teacher, usher, nursery, etc.) in church? There was a total of twenty-six points possible and the Family Influence Factor was calculated using the formula:

$$
F I F=(\text { total points awarded } \div 26) \times 100
$$

Finally, the Doctrinal Integrity Index is derived from the responses to thirty-three statements involving Christian doctrine and theological beliefs. These statements can be found on the survey in Appendix A, or they can also be found along with the responses that are consistent with a conservative evangelical doctrine in Table 1 on p.15 of this research. Responses were scored as follows:

1) Questions where agreement was consistent with conservative evangelical doctrine (\# 1-3, 7, 8, 10-16, 22, 26-28, 32, and 33)

\begin{tabular}{|c|c|}
\hline Response & Points \\
\hline STRONGLY AGREE (SA) & 3 \\
\hline AGREE (A) & 2 \\
\hline DISAGREE (D) & 1 \\
\hline STRONGLY DISAGREE (SD) & 0 \\
\hline
\end{tabular}

2) Questions where disagreement was consistent with conservative evangelical doctrine (\# 4-6, 9, 17-21, 23-25, and 29-31)

\begin{tabular}{|c|c|}
\hline Response & Points \\
\hline STRONGLY AGREE (SA) & 0 \\
\hline AGREE (A) & 1 \\
\hline DISAGREE (D) & 2 \\
\hline STRONGLY DISAGREE (SD) & 3 \\
\hline
\end{tabular}


There was a total of ninety-nine points possible and the Doctrinal Integrity Index was calculated using the formula:

$$
D I I=(\text { total points awarded } \div 99) \times 100
$$

\section{The Participants}

A total of 91 usable surveys were collected. Surveys were deemed unusable if they were incomplete, or if the person surveyed had been home-schooled during the seventh through twelfth grades. Home-schooler's surveys were discarded to eliminate that particular variable. None of the young adults surveyed had Catholic school, or nonChristian private school experience. At the end of the 2004-2005 school year, the Bible teachers at both the Dayton Christian and Xenia Christian Schools administered the survey to the outgoing seniors in their Bible class that had reached the age of eighteen. A total of 63 usable surveys were collected. Of this group, 56 had met the criteria of four or more years of grades seven through twelve in a Christian school, 7 did not. Local churches, Campus Crusade, and Athletes in Action were contacted to achieve an adequate sample of subjects that did not have the Christian school experience. The researcher was able to survey young people from three local churches and to collect an additional 28 surveys. In all, 60 of those surveyed met the Christian school criteria and 31 did not. Due to survey limitations, a response of "other Christian school" can only be interpreted as schools that are not public, Catholic, non-Christian private, or home school. The assumption was made that these schools are generally similar in regards to doctrine and overall mission to Dayton Christian Schools and will be included as Christian school experience. 
The age and gender distribution of the participants is indicated in Table 2.

Table 2: Age and gender distribution of survey participants.

\begin{tabular}{|l|c|c|c|}
\hline & $\begin{array}{c}\text { AVERAGE } \\
\text { AGE }\end{array}$ & \# MALE / \% & \# FEMALE / \% \\
\hline Met Christian ed. criteria & 18.2 & $36 / 60 \%$ & $24 / 40 \%$ \\
\hline Did not meet criteria & 18.97 & $10 / 32.3 \%$ & $21 / 67.7 \%$ \\
\hline Total & 18.46 & $46 / 50.5 \%$ & $45 / 49.5 \%$ \\
\hline
\end{tabular}

In addition, Table 3 presents the number and percent of respondents that indicated that they had attended a Christian college or university following graduation.

Table 3: Christian college or university attendance among survey participants

\begin{tabular}{|l|c|c|}
\hline & \# ATTENDED / \% & \# NOT ATTENDED / \% \\
\hline Met Christian ed. criteria & $2 / 3.3 \%$ & $58 / 96.7 \%$ \\
\hline Did not meet criteria & $12 / 38.7 \%$ & $19 / 61.3 \%$ \\
\hline Total & $14 / 15.4 \%$ & $77 / 84.6 \%$ \\
\hline
\end{tabular}

Finally, every participant satisfied the requirement of being a professing Christian, as evaluated by the aforementioned methodology.

\section{The Variables}

Independent Variables

The independent variables in this study include the following:

(1) The number of years that a student attended Christian school during the seventh through twelfth grades.

(2) Attending a Christian college or university following graduation from high school. 
(3) The Church Involvement Factor (CIF) as evidenced by a set of survey questions.

(4) The Family Influence Factor (FIF) as evidenced by a set of survey questions.

(5) The total number of years that a student attended Christian school from grades kindergarten through twelfth.

\section{Dependent Variable}

The dependent variable in this study is the Doctrinal Integrity Index (DII) as evidenced by a set of survey questions. Differences in these scores of the survey participants were used to determine statistical significance. It is expected that each of the independent variables will have a positive influence on this dependent variable. 


\section{CHAPTER IV: \\ RESULTS}

\section{Doctrinal Responses}

The researcher used SPSS 14.0 for Windows (release 14.0.1) to compile the percent of responses (SA, A, D, and SD) for each of the doctrinal statements presented in that section of the survey. Percent responses were calculated separately for each group, those that met the Christian education criteria of four or more years during seventh through twelfth grades and those that did not. Those results are presented in Table 4 . Individual responses are found in Appendix B.

Table 4: A comparison of doctrinal responses-

$4+$ years of Christian education ( $n=60)$ vs. $<4$ years of Christian education $(n=31)$ [Christian education is during grades 7-12, Percents are rounded to nearest tenth]

\begin{tabular}{|c|c|c|c|c|c|}
\hline SURVEY QUESTION & RESPONDENT & \% SA & $\% \mathrm{~A}$ & $\% \mathrm{D}$ & $\%$ SD \\
\hline \multirow{2}{*}{$\begin{array}{l}\text { The Bible is totally accurate in all of its } \\
\text { teachings }\end{array}$} & 4+ years Christian Ed. & 85.0 & 11.7 & 3.3 & 0.0 \\
\hline & $<4$ years Christian Ed. & 90.3 & 9.7 & 0.0 & 0.0 \\
\hline \multirow{2}{*}{$\begin{array}{l}\text { You, personally, have a responsibility to tell } \\
\text { other people of your religious beliefs. }\end{array}$} & 4+ years Christian Ed. & 50.0 & 50.0 & 0.0 & 0.0 \\
\hline & $<4$ years Christian Ed. & 83.9 & & & 0.0 \\
\hline \multirow{2}{*}{$\begin{array}{l}\text { Your religious faith is very important in your } \\
\text { life. }\end{array}$} & $4+$ years $\mathrm{Ch}$ & 56.7 & 41.7 & 1.7 & 0.0 \\
\hline & $<4$ years $\mathrm{Cl}$ & 80.6 & 19.4 & 0.0 & 0.0 \\
\hline \multirow{2}{*}{$\begin{array}{l}\text { The devil, or Satan, is not a living being but } \\
\text { is a symbol of evil. }\end{array}$} & $4+$ years $C$ & 3.3 & 6.7 & 23.3 & 66.7 \\
\hline & $<4 \mathrm{y}$ & 6.5 & 12.9 & 16.1 & 64.5 \\
\hline \multirow{2}{*}{$\begin{array}{l}\text { If a person is generally good, or does enough } \\
\text { good things for others during his or her life, } \\
\text { he or she will earn a place in heaven. }\end{array}$} & & 0.0 & 1.7 & 18.3 & 80.0 \\
\hline & $<4$ years $\mathrm{Cl}$ & 3.2 & 3.2 & 9.7 & 83.9 \\
\hline \multirow{2}{*}{$\begin{array}{l}\text { When Jesus Christ lived on Earth, He } \\
\text { committed sins, like other people. }\end{array}$} & $4+$ years $\mathrm{Ch}$ & 0.0 & 1.7 & 6.7 & 91.7 \\
\hline & $<4$ years $\mathrm{Ch}_{1}$ & 6.5 & 0.0 & 3.2 & 90.3 \\
\hline \multirow[t]{2}{*}{ Prayer can change what happens in life. } & $4+$ years $\mathrm{Ch}$ & 51.7 & 46.7 & 1.7 & 0.0 \\
\hline & $<4$ years $\mathrm{Ch}$ & 58.1 & 35.5 & 3.2 & 3.2 \\
\hline \multirow[t]{2}{*}{ Jesus Christ was a real person. } & & 86.7 & 11.7 & 1.7 & 0.0 \\
\hline & & 93.5 & 6.5 & 0.0 & 0.0 \\
\hline \multirow{2}{*}{$\begin{array}{l}\text { A person can lead a full and satisfying life } \\
\text { even if he or she does not pursue spiritual } \\
\text { development or maturity. }\end{array}$} & & 1.7 & 25.0 & 50.0 & 23.3 \\
\hline & $<4$ years Christian Ed. & 6.5 & 9.7 & 54.8 & 29 \\
\hline \multirow{2}{*}{$\begin{array}{l}\text { People who do not consciously accept Jesus } \\
\text { Christ as their Savior will be condemned to } \\
\text { hell. }\end{array}$} & $4+$ years $\mathrm{Cl}$ & 48.3 & 41.7 & 10.0 & 0.0 \\
\hline & $<4$ years Christian Ed. & 54.8 & 38.7 & 3.2 & 3.2 \\
\hline \multirow{2}{*}{$\begin{array}{l}\text { Forgiveness of sins is only possible through } \\
\text { faith in Jesus Christ. }\end{array}$} & & 80.0 & 20.0 & 0.0 & 0.0 \\
\hline & $<4$ years Christian Ed & 93.5 & 0.5 & 0.0 & 0.0 \\
\hline
\end{tabular}




\begin{tabular}{|c|c|c|c|c|c|}
\hline SURVEY QUESTION & RESPONDENT & $\% \mathbf{S A}$ & $\% \mathrm{~A}$ & $\% \mathrm{D}$ & $\% \mathrm{SD}$ \\
\hline \multirow[t]{2}{*}{ Angels exist and influence people's lives. } & 4+ years Christian Ed. & 41.7 & 56.7 & 1.7 & 0.0 \\
\hline & $<4$ years Christian Ed. & 41.9 & 41.9 & 12.9 & 3.2 \\
\hline \multirow[t]{2}{*}{ The universe was originally created by God. } & 4+ years Christian Ed. & 91.7 & 8.3 & 0.0 & 0.0 \\
\hline & $<4$ years Christian Ed. & 100.0 & 0.0 & 0.0 & 0.0 \\
\hline \multirow{2}{*}{$\begin{array}{l}\text { All people will be judged by God after they } \\
\text { die, regardless of their religious beliefs. }\end{array}$} & 4+ years Christian Ed. & 83.3 & 16.7 & 0.0 & 0.0 \\
\hline & $<4$ years Christian Ed. & 93.5 & 6.5 & 0.0 & 0.0 \\
\hline \multirow[t]{2}{*}{ Jesus Christ was born to a virgin. } & 4+ years Christian Ed. & 83.3 & 11.7 & 0.0 & 0.0 \\
\hline & $<4$ years Christian Ed. & 96.8 & 3.2 & 0.0 & 0.0 \\
\hline \multirow{2}{*}{$\begin{array}{l}\text { All of the miracles described in the Bible } \\
\text { actually took place. }\end{array}$} & 4+ years Christian Ed. & 85.0 & 15.0 & 0.0 & 0.0 \\
\hline & $<4$ years Christian Ed. & 87.1 & 12.9 & 0.0 & 0.0 \\
\hline \multirow[t]{2}{*}{ The whole idea of sin is outdated. } & 4+ years Christian Ed. & 0.0 & 1.7 & 16.7 & 81.7 \\
\hline & $<4$ years Christian Ed. & 0.0 & 3.2 & 9.7 & 87.1 \\
\hline \multirow[t]{2}{*}{ All religious faiths teach equally valid truths. } & 4+ years Christian Ed. & 0.0 & 13.3 & 33.3 & 53.3 \\
\hline & $<4$ years Christian Ed. & 0.0 & 6.5 & 22.6 & 71.0 \\
\hline \multirow{2}{*}{$\begin{array}{l}\text { After death, people are reincarnated-that is, } \\
\text { they return to Earth in another life form. }\end{array}$} & 4+ years Christian Ed. & 1.7 & 0.0 & 15.0 & 83.3 \\
\hline & $<4$ years $\mathrm{Ch}$ & 0.0 & 0.0 & 9.7 & 90.3 \\
\hline \multirow{2}{*}{$\begin{array}{l}\text { The Holy Spirit is a symbol of God's } \\
\text { presence or power but is not a living entity. }\end{array}$} & 4+ years Christ & 1.7 & 6.7 & 30.0 & 61.7 \\
\hline & $<4$ years Christian Ed. & 0.0 & 9.7 & 22.6 & 67.7 \\
\hline \multirow{2}{*}{$\begin{array}{l}\text { After He was crucified and died, Jesus Christ } \\
\text { did not return to life physically. }\end{array}$} & 4+ years Christian Ed. & 5.0 & 3.3 & 13.3 & 78.3 \\
\hline & $<4$ years $\mathrm{C}$ & 6.5 & 6.5 & 9.7 & 77.4 \\
\hline \multirow{2}{*}{$\begin{array}{l}\text { Your religious beliefs actually change the } \\
\text { way you behave. }\end{array}$} & $4+$ years $\mathrm{Cl}$ & 63.3 & 30.0 & 5.0 & 1.7 \\
\hline & $<4$ years Christian Ed. & 90.3 & 9.7 & 0.0 & 0.0 \\
\hline \multirow{2}{*}{$\begin{array}{l}\text { God created humans, but He is no longer } \\
\text { personally involved in your life or } \\
\text { experiences. }\end{array}$} & 4+ years Christian Ed. & 0.0 & 0.0 & 18.3 & 81.7 \\
\hline & $<4$ years Christian Ed. & 0.0 & 0.0 & 12.9 & 87.1 \\
\hline \multirow{2}{*}{$\begin{array}{l}\text { There are some crimes, sins, or other } \\
\text { behaviors people do that are so terrible that } \\
\text { they cannot be forgiven by God. }\end{array}$} & $4+$ years $C$ & 0.0 & 5.0 & 30.0 & 65.0 \\
\hline & $<4$ years Christian Ed. & 0.0 & 0.0 & 9.7 & 90.3 \\
\hline \multirow{2}{*}{$\begin{array}{l}\text { It doesn't matter what religious faith you } \\
\text { associate with because they all believe the } \\
\text { same principles and truths. }\end{array}$} & 4+ years Chris & 0.0 & 3.3 & 21.7 & 75.0 \\
\hline & $<4$ years Christian Ed. & 0.0 & 0.0 & 9.7 & 90.3 \\
\hline \multirow{2}{*}{$\begin{array}{l}\text { Your religious beliefs are not likely to } \\
\text { change in the future. }\end{array}$} & $4+$ years & 36.7 & 31.7 & 21.7 & 10.0 \\
\hline & $<4$ years Christ & 54.8 & 22.6 & 16.1 & 6.5 \\
\hline \multirow{2}{*}{$\begin{array}{l}\text { The Christian faith is relevant to your life } \\
\text { today. }\end{array}$} & 4+ years Christian Ed. & 76.7 & 21.7 & 1.7 & 0.0 \\
\hline & $<4$ years $\mathrm{C}$ & 83.9 & 12.9 & 3.2 & 0.0 \\
\hline \multirow{2}{*}{$\begin{array}{l}\text { The Bible provides a clear and totally } \\
\text { accurate description of moral truth. }\end{array}$} & 4+ years Christian Ed. & 66.7 & 26.7 & 6.7 & 0.0 \\
\hline & $<4$ years $\mathrm{Ch}$ & 74.2 & 22.6 & 3.2 & 0.0 \\
\hline \multirow{2}{*}{$\begin{array}{l}\text { What you do for other people is more } \\
\text { important than what you believe about Jesus } \\
\text { Christ. }\end{array}$} & 4+ years Christian Ed. & 1.7 & 3.3 & 41.7 & 53.3 \\
\hline & $<4$ years Christian Ed. & 0.0 & 0.0 & 35.5 & 64.5 \\
\hline \multirow{2}{*}{$\begin{array}{l}\text { The Bible does not provide many practical } \\
\text { standards for living in today's world. }\end{array}$} & $4+$ years $C$ & 0.0 & 8.3 & 43.3 & 48.3 \\
\hline & $<4$ years Christian Ed. & 0.0 & 3.2 & 16.1 & 80.6 \\
\hline \multirow{2}{*}{$\begin{array}{l}\text { Anyone who relies upon the Bible for moral } \\
\text { guidance is foolish. }\end{array}$} & 4+ years Christ & 1.7 & 0.0 & 21.7 & 76.7 \\
\hline & $<4$ years Christian Ed. & 0.0 & 0.0 & 12.9 & 87.1 \\
\hline
\end{tabular}




\begin{tabular}{|l|c|c|c|c|c|}
\hline \multicolumn{1}{|c|}{ SURVEY QUESTION } & RESPONDENT & \% SA & \% A & \% D & \% SD \\
\hline \multirow{2}{*}{$\begin{array}{l}\text { God is the all-knowing and all-powerful } \\
\text { perfect Creator of the universe who still rules } \\
\text { the world today. }\end{array}$} & 4+ years Christian Ed. & 93.3 & 6.7 & 0.0 & 0.0 \\
\cline { 2 - 6 } & $<4$ years Christian Ed. & 93.5 & 3.2 & 0.0 & 3.2 \\
\hline $\begin{array}{l}\text { You feel it is important to be a member of a } \\
\text { church. }\end{array}$ & 4+ years Christian Ed. & 58.3 & 38.3 & 3.3 & 0.0 \\
\cline { 2 - 6 } & $<4$ years Christian Ed. & 67.7 & 25.8 & 6.5 & 0.0 \\
\hline
\end{tabular}

\section{Research Question \#1}

The researcher used SPSS 14.0 for Windows (release 14.0.1) to run an independent samples t-test on the data, using whether or not the respondents had met the criteria of four or more years of Christian education in the seventh through twelfth grades as the independent variable and the Doctrinal Integrity Index (DII) as the dependent variable. The mean DII of the group that met the Christian education criteria was 87.56 with a standard deviation of 9.51 and the mean DII of the group that did not was 90.91 with a standard deviation of 7.30 . The t-value was 1.72 with the degrees of freedom equaling 89 . At the á $=.05$, there is no statistical difference; therefore the researcher accepts the null hypothesis that there is no statistical difference in the doctrinal integrity of students that have attended Christian school for at least four years during grades seven through twelve and those that had not.

Figure 1: Comparison of mean Doctrinal Integrity Index based on Christian school criteria

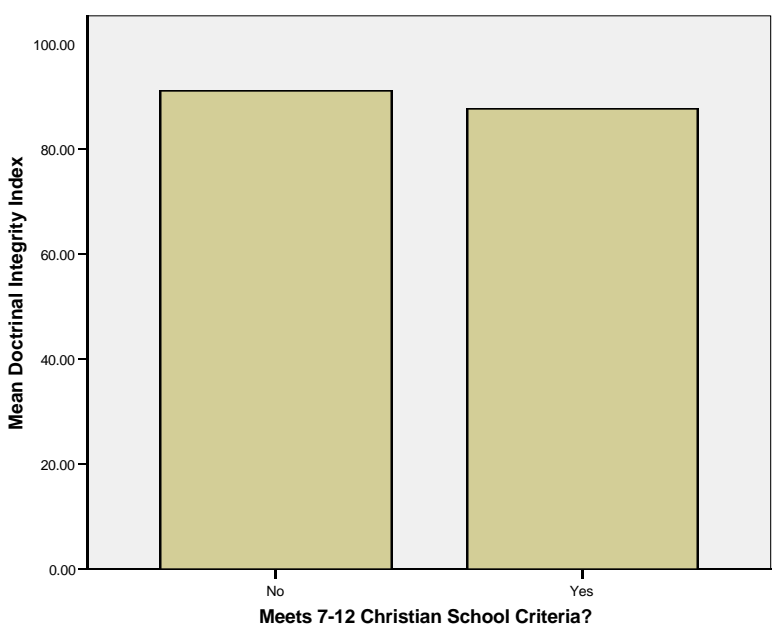


Figure 2: Comparison of frequency distributions of the Doctrinal Integrity Index based on Christian school criteria

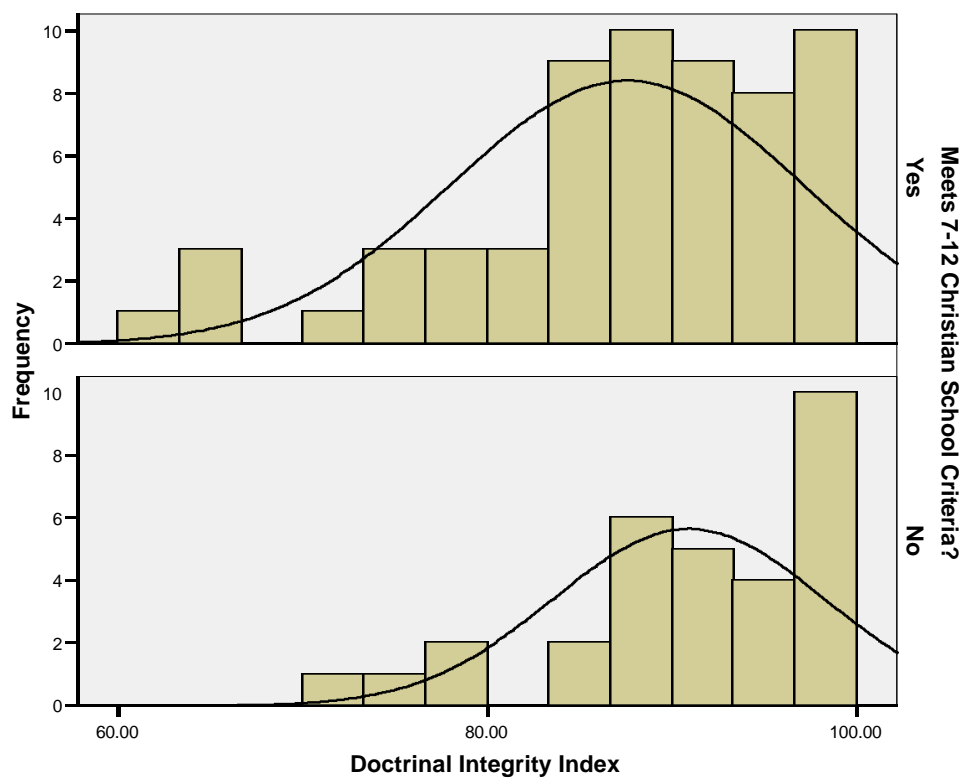

Because a far greater proportion of the group that did not meet the Christian school criteria had attended a Christian college or university after graduation (12 out of 31 versus 2 out of 60 ), it becomes necessary to see if there is a statistically significant difference in the mean DII of those in this group that did go to a Christian college following high school graduation, and those that did not. To test this, an independent samples t-test was conducted on the data, using whether or not the respondents had attended Christian college following high school graduation as the independent variable and the Doctrinal Integrity Index (DII) as the dependent variable. The mean DII of the group that had gone to Christian college was 93.10 with a standard deviation of 5.38 and the mean DII of the group that did not was 89.53 with a standard deviation of 8.12 . The t-value was 1.35 with the degrees of freedom equaling 29 . At the á $=.05$, there is no statistical difference; therefore the researcher accepts the null hypothesis that there is no statistical difference in the doctrinal integrity of students that have attended a Christian 
college following graduation and those that had not. This factor can therefore be disregarded as a significant producer of bias in the primary research question.

Figure 3: Comparison of mean Doctrinal Integrity Index based on attending Christian college following high school graduation

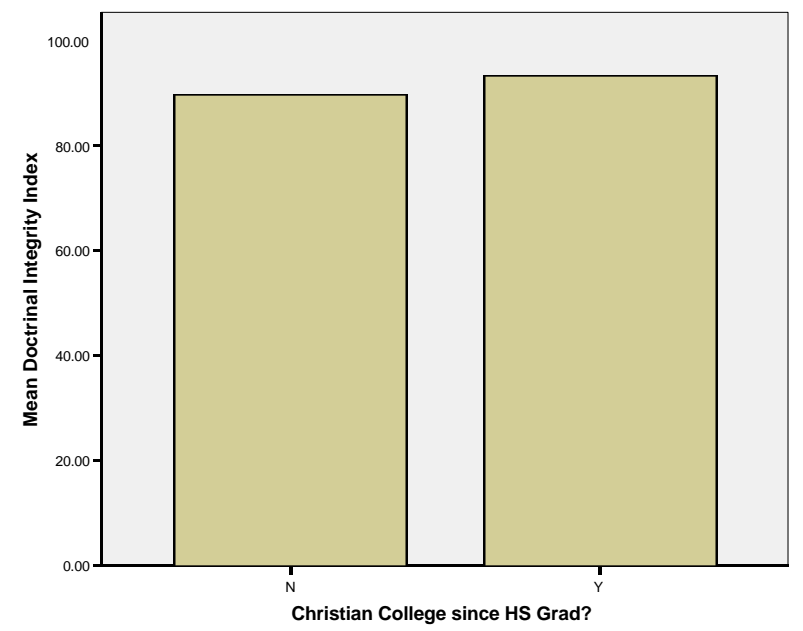




\section{Research Question \#2}

A Pearson one-tail test was used to determine the correlation between the Family Influence Factor (FIF) and the Doctrinal Integrity Index (DII). With 89 degrees of freedom, $r=.193$. At the á $=.05$, there is a statistically significant correlation; therefore the researcher rejects the null hypothesis, accepting the alternative hypothesis that there is a significant correlation between a participant's Family Influence Factor and their Doctrinal Integrity Index. However, it is important to note that this correlation is quite weak.

Figure 4: Scatter-plot of the correlation between Doctrinal Integrity Index and Family Influence Factor

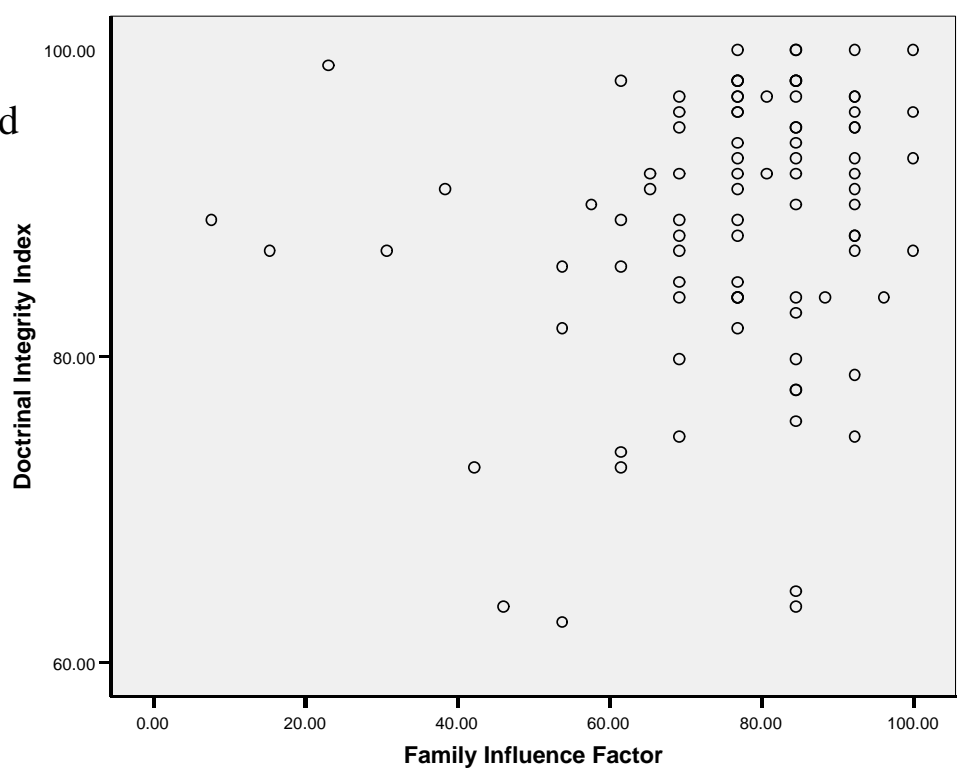




\section{Research Question \#3}

A Pearson one-tail test was used to determine the correlation between the Church Involvement Factor (CIF) and the Doctrinal Integrity Index (DII). With 89 degrees of freedom, $r=.345$. At the á $=.01$, there is a statistically significant correlation; therefore the researcher rejects the null hypothesis, accepting the alternative hypothesis that there is a significant correlation between a participant's Church Involvement Factor and their Doctrinal Integrity Index.

Figure 5: Scatter-plot of the Correlation between Doctrinal Integrity Index and Church Involvement Factor

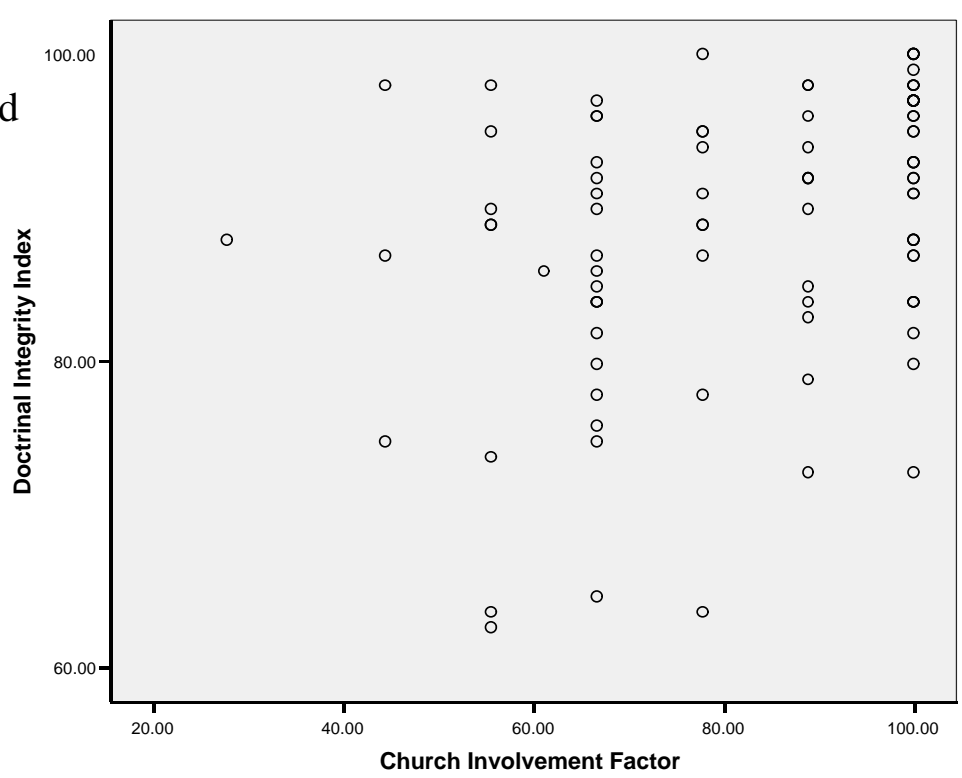




\section{Research Question \#4}

A Pearson one-tail test was used to determine the correlation between the total number of years that a participant attended a Christian school during grades kindergarten through twelfth and the Doctrinal Integrity Index (DII). With 89 degrees of freedom, $\mathrm{r}=.204$. The $\mathrm{a}=.05$ level revealed a statistically significant correlation. Finding this correlation to be very weak, the researcher decided to run an additional test.

Figure 5: Scatter-plot of the correlation between Doctrinal ${ }^{100.00}$ Integrity Index and the total years of Christian school $(\mathrm{K}-12)$

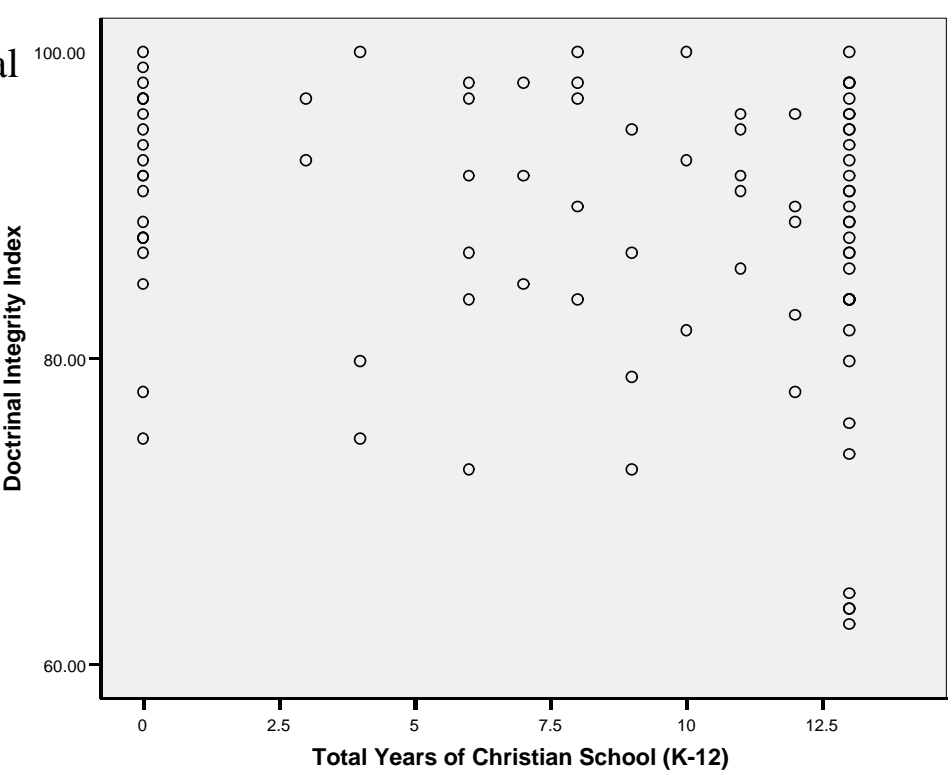

Because of the ranking nature of the total years of Christian school (K-12), the researcher ran a Kruskal-Wallis H test (see Table 5). "The Kruskal-Wallis H test is the equivalent of the one-way ANOVA for ranked scores" (Heiman, 2001, p.607). With 10 degrees of freedom, $\div^{2}=9.854$. At the á $=.05$, there is no statistical difference; therefore the researcher accepts the null hypothesis that there is no statistically significant correlation between the number of years that a participant had attended Christian school (K-12) and their Doctrinal Integrity Index. 
Table 5: Kruskal-Wallis H test Doctrinal Integrity Index rankings

\begin{tabular}{|c|c|c|}
\hline Total Years of Christian School (K-12) & N & Mean Rank \\
\hline 0 & 21 & 53.05 \\
\hline 3 & 2 & 66.25 \\
\hline 4 & 3 & 37.33 \\
\hline 6 & 6 & 44.83 \\
\hline 7 & 3 & 53.67 \\
\hline 8 & 5 & 62.40 \\
\hline 9 & 4 & 28.63 \\
\hline 10 & 3 & 54.33 \\
\hline 11 & 5 & 52.30 \\
\hline 12 & 5 & 36.60 \\
\hline TOTAL & 34 & 40.10 \\
\hline
\end{tabular}




\section{CHAPTER V: \\ SUMMARY, CONCLUSIONS, AND RECOMMENDATIONS}

\section{Summary}

The purpose of this study was to evaluate the effectiveness of Christian schools, partnered with the Christian home and church, in developing within their students a purely biblical worldview that is then reflected in their doctrinal beliefs later in life. The study was initially motivated by statistics that had been presented at an Association of Christian Schools International convention in October, 2002 by Josh McDowell. The lecture pointed to information in his book Beyond Belief to Convictions that indicate that "the postmodern influence has had a profound effect on what our kids believe about God, truth, and reality" (McDowell \& Hostetler, 2002, p.14). Beyond Belief to Convictions is largely based on research presented by George Barna in his book Real Teens (cf. Barna, 2001). As a Christian school teacher, the author desired to discover if the findings of George Barna were consistent among students that had gone to Christian school as well as those that had not. There was also a desire to explore the effects of the home and church on this observed decline in doctrinal integrity.

The findings of this research can be summarized as follows:

1. Young adults age eighteen to twenty-one that have attended a Christian school for at least four years of grades seven through twelve are not more likely to express beliefs that are consistent with evangelical doctrine than their public school peers?

2. The family's spiritual condition during grades seven through twelve, as evidenced through a set of survey questions, does significantly influence the doctrinal integrity 
of the same young adults, which may positively or negatively affect the efforts of the Christian school?

3. The degree of a student's church involvement during grades seven through twelve, as evidenced through a set of survey questions, does influence the doctrinal integrity of the same young adults, which may positively or negatively affect the efforts of the Christian school?

4. There is not a significant correlation between the number of years that a child has attended a Christian school (K-12) and their doctrinal integrity as a young adult?

\section{Conclusions}

The results of the study were inconclusive. Whereas students that met the Christian school criteria did not have a significantly greater mean doctrinal integrity than that of those that didn't, the responses of all those that were surveyed did not present as bleak a picture as that presented by Barna (cf. Barna, 2001). Table 6 presents a comparison of responses in this research versus that presented in Real Teens. For almost every question, there are a considerably smaller percentage of participants in this research that expressed beliefs that were contrary to a conservative evangelical doctrine than in Barna's research. In other words, although the experimental group did not show a significantly greater mean doctrinal integrity than the control group, the responses of both groups, with few exceptions, indicated a strong adherence to a conservative evangelical doctrine. Comparing the Christian school students surveyed in this report to the general teen population that was surveyed by Barna would indicate a greater level of adherence to conservative evangelical doctrine. 
Table 6: A Comparison of Doctrinal Responses for Selected Survey QuestionsBarna's Research (Barna, 2001, pp.131, 132) vs. This Research

\begin{tabular}{|c|c|c|c|}
\hline SURVEY QUESTION & SOURCE & $\%$ SA or A & $\%$ SD or D \\
\hline \multirow{2}{*}{$\begin{array}{l}\text { The Bible is totally accurate in all of its } \\
\text { teachings }\end{array}$} & Barna Research & 86.0 & 13.0 \\
\hline & This Research & 97.8 & 2.2 \\
\hline \multirow{2}{*}{$\begin{array}{l}\text { You, personally, have a responsibility to tell } \\
\text { other people of your religious beliefs. }\end{array}$} & Barna Research & 79.0 & 21.0 \\
\hline & This Research & 100.0 & 0.0 \\
\hline \multirow{2}{*}{$\begin{array}{l}\text { The devil, or Satan, is not a living being but } \\
\text { is a symbol of evil. }\end{array}$} & Barna Research & 55.0 & 41.0 \\
\hline & This Research & 13.2 & 86.8 \\
\hline \multirow{2}{*}{$\begin{array}{l}\text { If a person is generally good, or does enough } \\
\text { good things for others during his or her life, } \\
\text { he or she will earn a place in heaven. }\end{array}$} & Barna Research & 48.0 & 52.0 \\
\hline & This Research & 3.3 & 96.7 \\
\hline \multirow{2}{*}{$\begin{array}{l}\text { When Jesus Christ lived on Earth, He } \\
\text { committed sins, like other people. }\end{array}$} & Barna Research & 40 & 58 \\
\hline & This Research & 3.3 & 96.7 \\
\hline \multirow[t]{2}{*}{ Prayer can change what happens in life. } & Barna Research & 97.0 & 3.0 \\
\hline & This Research & 96.7 & 3.3 \\
\hline \multirow[t]{2}{*}{ Jesus Christ was a real person. } & Barna Research & 90.0 & 6.0 \\
\hline & This Research & 98.9 & 1.1 \\
\hline \multirow{2}{*}{$\begin{array}{l}\text { A person can lead a full and satisfying life } \\
\text { even if he or she does not pursue spiritual } \\
\text { development or maturity. }\end{array}$} & Barna Research & 44.0 & 55.0 \\
\hline & This Research & 23.1 & 76.9 \\
\hline \multirow{2}{*}{$\begin{array}{l}\text { People who do not consciously accept Jesus } \\
\text { Christ as their Savior will be condemned to } \\
\text { hell. }\end{array}$} & Barna Research & 67.0 & 32.0 \\
\hline & This Research & 91.2 & 8.8 \\
\hline \multirow{2}{*}{$\begin{array}{l}\text { Forgiveness of sins is only possible through } \\
\text { faith in Jesus Christ. }\end{array}$} & Barna Research & 88.0 & 12.0 \\
\hline & This Research & 100.0 & 0.0 \\
\hline \multirow{2}{*}{$\begin{array}{l}\text { All people will be judged by God after they } \\
\text { die, regardless of their religious beliefs. }\end{array}$} & Barna Research & 73.0 & 26.0 \\
\hline & This Research & 100.0 & 0.0 \\
\hline \multirow[t]{2}{*}{ Jesus Christ was born to a virgin. } & Barna Research & 78.0 & 19.0 \\
\hline & This Research & 100.0 & 0.0 \\
\hline \multirow{2}{*}{$\begin{array}{l}\text { All of the miracles described in the Bible } \\
\text { actually took place. }\end{array}$} & Barna Research & 95.0 & 5.0 \\
\hline & This Research & 100.0 & 0.0 \\
\hline \multirow[t]{2}{*}{ All religious faiths teach equally valid truths. } & Barna Research & 53.0 & 45.0 \\
\hline & This Research & 11.0 & 89.0 \\
\hline \multirow{2}{*}{$\begin{array}{l}\text { After death, people are reincarnated-that is, } \\
\text { they return to Earth in another life form. }\end{array}$} & Barna Research & 17.0 & 82.0 \\
\hline & This Research & 1.1 & 98.9 \\
\hline
\end{tabular}

Note: Barna's percentages may not add up to 100 due to exclusion of those who responded "don't know."

There are several possible explanations why the discouraging result of Barna's research is not observed to the same extent in this research. For example, Barna surveyed "teens" which could include students as young as thirteen. This research included only 
those eighteen to twenty-one with an average age of 18.46 years. One would expect that with age, exposure to Christian teachings and doctrine would be more complete and comprehensive. Also, students in their early teens may be at a more rebellious stage of development and therefore either less inhibited or even desiring to express beliefs that go against what they believe is expected of them.

In addition, this research was limited to respondents that were all either in a Christian school or in a church setting. The vast majority of those surveyed in this research attend evangelical churches that tend toward being more conservative. All surveys were completed either at a conservative evangelical church, or at a Christian school that requires church attendance. Barna had access to a much more diverse group of young people. Although they met the same standard for being considered "bornagain" as was used in this research, their church participation could have been nonexistent, non-evangelical, or theologically liberal.

This factor becomes extremely significant when other findings of this research are taken into consideration. Church involvement was the factor researched that showed the strongest correlation to increased doctrinal integrity. It is of utmost importance that young people be actively involved in church. Within the survey, the Church Involvement Factor was most influenced by frequency of church attendance (being involved beyond just a Sunday morning service) and consistent participation in a youth group. It is the conclusion of this researcher that every effort should be made to encourage active participation in a church that teaches the truth of the Bible and has a youth program that challenges and engages the students. 
The researcher was quite surprised that there was such a weak correlation between the Family Influence Factor and doctrinal integrity. It is the personal belief of the author, that the family should have the greatest influence on a young person's spiritual development. However, there are so many factors in the family dynamic that can affect the end result in the children that are raised. Sibling interaction is one factor not addressed by this research, as are other outside pressures that influence the family environment. It is believed that results observed regarding family influence in this research have been affected by the limitations of the survey in accurately quantifying the influence that a family has on a young person. An accurate measure of a family's influence on spiritual formation may not be achievable with a limited survey instrument, requiring instead extensive research and observation well beyond the scope of this study.

\section{Recommendations}

This research confirms McDowell and Hostetler's (2002, p.298) conclusion that "the ideal way to help our kids not only to reject the postmodern worldview but also embrace deepened Christian convictions is to align church, home, and school into a unified whole that arms our children with the truth and protects them from distortions." How confusing it must be for a student to be taught a biblical worldview at church, have inconsistencies modeled at home, and be indoctrinated with a completely different worldview at school. It is no wonder that Christianity is plagued with "spiritual schizophrenia." "True education can not exist without both of these foundational building blocks_-Jesus Christ and God's Word—in place at all times...If God's plan for education is to be fully effective in the lives of our children, these foundational elements 
must undergird our children's entire educational process. They must be present in the home, the church, and the school" (Schultz, 2002, p.33). This three pronged approach to spiritual formation has been compared to a milking stool. A one-legged milking stool would not be very stable. Likewise, a two-legged milking stool would also lack stability. However, when that milking stool has three legs it becomes quite functional. In regards to spiritual formation in a student, it is best when the church, home, and family all work together on common ground. The Christian school is impotent when students go home to families that are not fully committed to living and growing in the Christian life. The Christian school is simply an extension of the home where Deuteronomy 6:7 gives parents the following mandate. "You shall teach [God's words] diligently to your sons and shall talk of them when you sit in your house and when you walk by the way and when you lie down and when you rise up." Likewise, the Christian school is to be a support to the Bible teaching church, as both the church and school seek to support the spiritual needs of the family. This three pronged approach to spiritual formation in our students is the most effective way of preventing the deterioration of doctrinal integrity in young people that are bombarded daily with the postmodern philosophy so present in our culture today.

In researching postmodernism, it is also the opinion of the author that Christian schools need to modify the way that they minister to the students that are entrusted to them. If our schools continue to teach in ways characteristic of a modernistic ethos, the battle for the hearts and minds of our students will be lost. Many texts have been written for youth pastors in regards to taking advantage of postmodernism, likewise teachers in Christian schools need to be equipped and prepared. Christian Schools need to continue 
to be a place where the absolute truth and authority of God and the Bible is maintained and proclaimed. While maintaining truth, the educational process must seek to take advantage of the positives of postmodernism. Teachers need to make the educational process relevant to the lives of their students. There is a need to not just isolate students from the world and culture in which they live, but instead to teach them how to engage their culture from a Biblical worldview. Christian school classrooms need to become learning communities where students find safety, love, and understanding, instead of condemnation. While at the same time, Biblical truth and admonition in righteousness is never compromised. Teachers need to develop a positive relationship with their students, gaining their trust and respect. Likewise, teachers need to be models of Christ and holiness. The Christian school should be a place of grace where repentance and forgiveness is practiced; where student and teacher travel together down the road to become a little bit more like Christ each and every day. The Christian school classroom needs to be a place of hope in a hopeless world.

If further research were to be done in this topic, the author would make several changes or recommendations. First, a much more comprehensive survey instrument would be designed. The one that was used was designed to be brief enough to not be intimidating to those being surveyed and yet gain sufficient insight to answer the proposed questions. However, as was previously mentioned a much more extensive survey would be required to gain a more accurate understanding of the family environment and experiences of the young person being surveyed. Likewise, a more extensive survey could help produce an improved assessment of the student's church experience and involvement. 
In addition, the author would choose to broaden the scope of those surveyed. Effort would be made to enlist the help of Christian schools throughout the country, so as to eliminate any regional bias that may be present. This would also greatly increase the sample size. Furthermore, he would persevere at finding sources of students that did not meet the Christian school criteria outside of the church. Many attempts were made to survey students in various campus ministries, but the author was unable to enlist the help of those groups. It is believed that these groups would provide not only a much larger sample, but also a much more heterogeneous sample than found in church youth and college groups.

Regardless of the difficulties and limitations that have been encountered in this research, it is clear that Christian schools, families, and churches face both a great challenge and opportunity as they seek to minister to the children whose lives they are privileged to influence. Every effort must be made to take advantage of the positive aspects of postmodernism, while simultaneously striving to neutralize its harmful components. 


\section{POST-HIGH SCHOOL BELIEFS SURVEY}

(To be completed only by those age 18 to 21 )

By completing this survey, you acknowledge that you meet this age requirement and that you give permission for your anonymous responses to be used for the purpose of educational research.

Dear Participant:

I want to take a moment to first thank you for taking part in this survey.

The information that is collected will be critical in answering some important questions that I am researching. To do this, I need to gather some background information about the educational experiences of people age 18 to 21 , as well as some information about their beliefs and attitudes toward church and religion.

As you can see, there is no place on this survey for your name or the name of your church. This is completely anonymous, so you can answer the questions honestly and express what you truly believe in your heart.

Often times, people that go to church know how they should answer questions about God and the Bible, but I want you to answer the following questions with how you truly believe in your heart. I am not looking for any right or wrong answers, but instead, I'm trying to gain insight on the honest beliefs of young adults.

Thanks again for your valuable help in this research. 
Gender: MALE FEMALE

Age:

Please circle which grades you attended each of the following types of schools:

Public School

Catholic School

$\begin{array}{lllllll:llllll}\mathrm{K} & 1 & 2 & 3 & 4 & 5 & 6 & 7 & 8 & 9 & 10 & 11 & 12 \\ \mathrm{~K} & 1 & 2 & 3 & 4 & 5 & 6 & 7 & 8 & 9 & 10 & 11 & 12 \\ \mathrm{~K} & 1 & 2 & 3 & 4 & 5 & 6 & 7 & 8 & 9 & 10 & 11 & 12 \\ \mathrm{~K} & 1 & 2 & 3 & 4 & 5 & 6 & 7 & 8 & 9 & 10 & 11 & 12 \\ & & & & & & & & & & & & \\ \mathrm{~K} & 1 & 2 & 3 & 4 & 5 & 6 & 7 & 8 & 9 & 10 & 11 & 12 \\ \mathrm{~K} & 1 & 2 & 3 & 4 & 5 & 6 & 7 & 8 & 9 & 10 & 11 & 12\end{array}$

Any campus of Dayton Christian Including Xenia Christian

Any other Christian School

(not Catholic)

Non-Christian Private School

Home School

Which of the following best describes your activity following high school?

Attended Christian College or University Attended non-Christian College or University Directly entered the workplace without College or University experience

Have you ever made a personal commitment to Jesus Christ that is important in your life today? YES NO

If YES, which statement below best describes your belief about eternity or the afterlife?

\section{(CHECK ONE) WHEN I DIE...}

I will go to heaven because a loving God would never send someone to hell.

I will go to heaven because I have confessed my sins and have accepted Jesus Christ as Savior. I will go to heaven because I do more good things than I do bad things. I will go to heaven because there is not an actual place called hell. I will go to hell because I'm not good enough for heaven. I will not go to heaven or hell because neither is real-I will simply cease to exist. I will not go to heaven or hell because I will be reincarnated.

Please answer the following questions about your church experience during the time you were in grades seven through twelve.

How often did you go to church? (Check one) SELDOM

1 OR 2 TIMES A MONTH WEEKLY TWICE A WEEK OR MORE

How would you describe your participation in youth group? (Check one) NEVER SELDOM 1 OR 2 TIMES A MONTH WEEKLY

I attended church at least twice a month during: (Check all that apply) grades $\mathrm{K}$ to 6 grades 7 to 8 grades 9 to 12 the time since graduation 
Please answer the following questions about your family experience during the time you were in grades seven through twelve.

Who most influenced your going to church? (Check one)

PARENTS

OTHER RELATIVES

FRIENDS

I WENT ON MY OWN

Which of the parents that you lived with during the time that you were in grades seven through twelve attended church?

BOTH _ ONE (single parent home)

ONE (two parent home)

NEITHER

If you checked one of the first three choices in the previous question, check the statement that best describes the level of their church attendance.

SELDOM

1 OR 2 TIMES A MONTH

WEEKLY

MORE THAN WEEKLY

For the next TWO questions, "routinely" means 3 to 4 or more times a week.

Did your family routinely do devotions together?

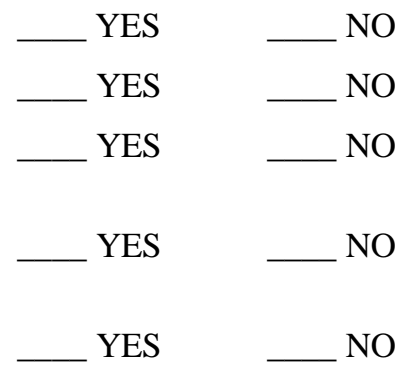

Did your family routinely pray together?

Did one or more parent attend Sunday school?

Did one or more parent participate in a church service or Bible study other than the regular church service?

Did one or more parent actively serve (teacher, usher, nursery, etc.) in the church?

For each of the following statements, circle:

\section{SA—strongly agree A-agree $\mathrm{D}$-disagree $\mathrm{SD}$-strongly disagree}

1. The Bible is totally accurate in all of its teachings

SA A D SD

2. You, personally, have a responsibility to tell other people of your religious beliefs.

3. Your religious faith is very important in your life.

4. The devil, or Satan, is not a living being but is a symbol of evil.

5. If a person is generally good, or does enough good things for others during his or her life, he or she will earn a place in heaven.

6. When Jesus Christ lived on Earth, He committed sins, like other people.

7. Prayer can change what happens in life.

8. Jesus Christ was a real person.

9. A person can lead a full and satisfying life even if he or she does not pursue spiritual development or maturity.

10. People who do not consciously accept Jesus Christ as their Savior will be condemned to hell.

SA A D SD

SA A D SD

SA A D SD

SA A D SD

SA A D SD

SA A D SD

SA A D SD

SA A D SD

SA A D SD 
11. Forgiveness of sins is only possible through faith in Jesus Christ.

12. Angels exist and influence people's lives.

13. The universe was originally created by God.

14. All people will be judged by God after they die, regardless of their religious beliefs.

15. Jesus Christ was born to a virgin.

16. All of the miracles described in the Bible actually took place.

17. The whole idea of sin is outdated.

18. All religious faiths teach equally valid truths.

19. After death, people are reincarnated - that is, they return to Earth in another life form.

20. The Holy Spirit is a symbol of God's presence or power but is not a living entity.

21. After He was crucified and died, Jesus Christ did not return to life physically.

22. Your religious beliefs actually change the way you behave.

23. God created humans, but He is no longer personally involved in your life or experiences.

24. There are some crimes, sins, or other behaviors people do that are so terrible that they cannot be forgiven by God.

25. It doesn't matter what religious faith you associate with because they all believe the same principles and truths.

26. Your religious beliefs are not likely to change in the future.

27. The Christian faith is relevant to your life today.

28. The Bible provides a clear and totally accurate description of moral truth.

29. What you do for other people is more important than what you believe about Jesus Christ.

30. The Bible does not provide many practical standards for living in today's world.

31. Anyone who relies upon the Bible for moral guidance is foolish.

32. God is the all-knowing and all-powerful perfect Creator of the universe who still rules the world today.

33. You feel it is important to be a member of a church.

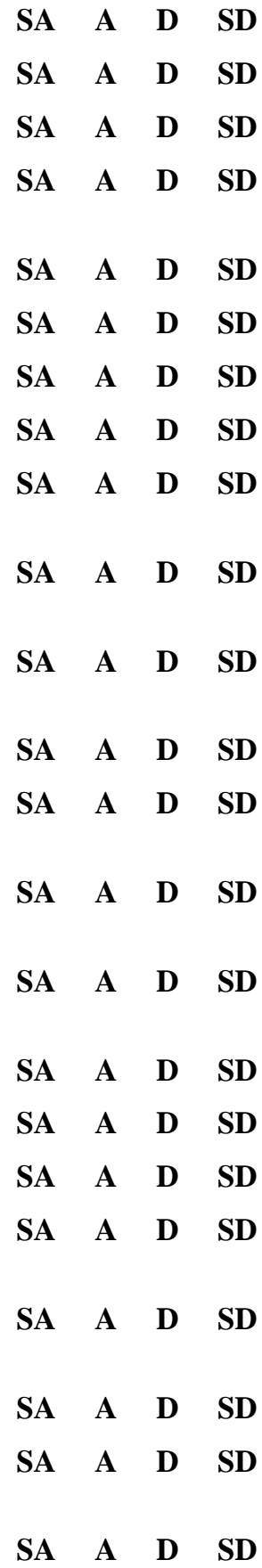

THANK YOU FOR COMPLETING THIS SURVEY!

PLEASE PLACE IT IN THE ENVELOPE PROVIDED

BY THE PERSON GIVING THE SURVEY. 


\section{Appendix B}

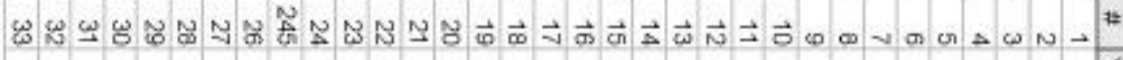

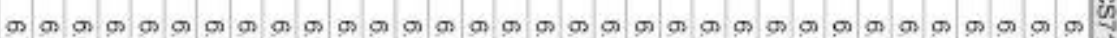
888888888888888888888888888888888

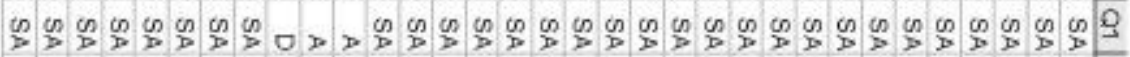

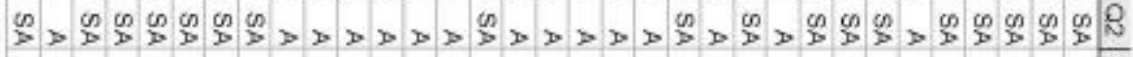

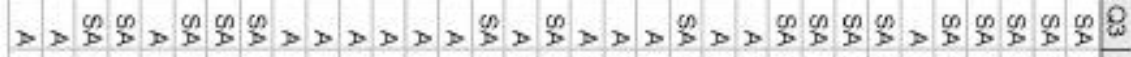

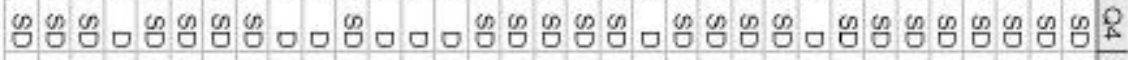

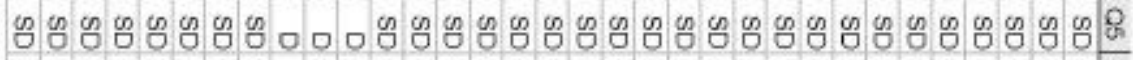

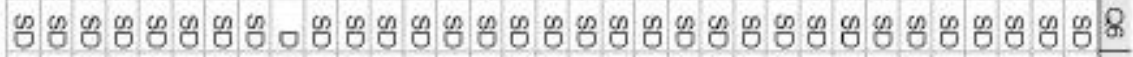

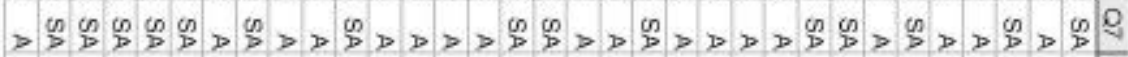

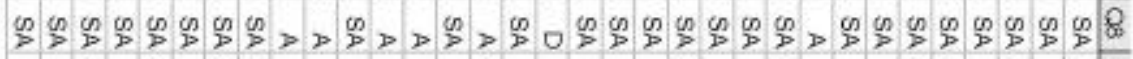

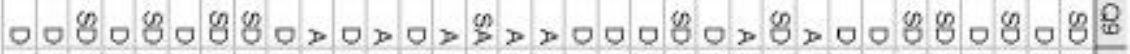

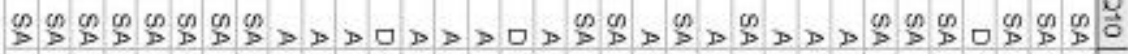

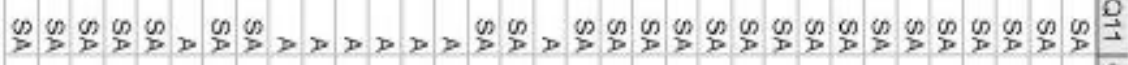

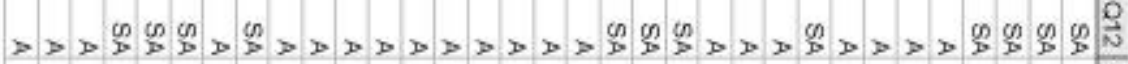

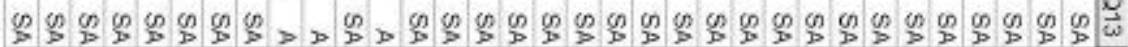

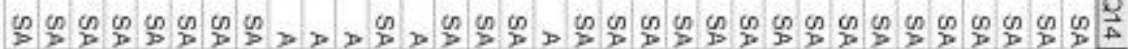

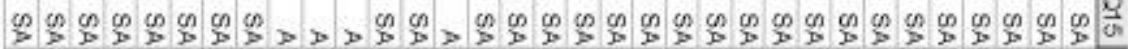

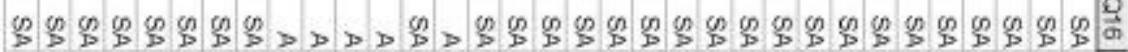

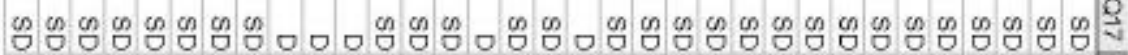

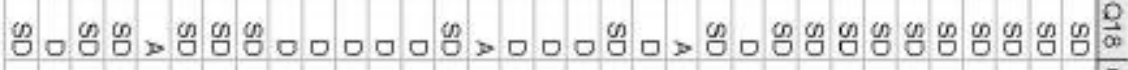

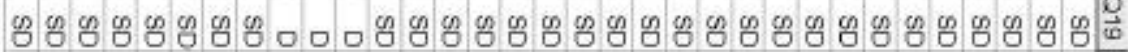

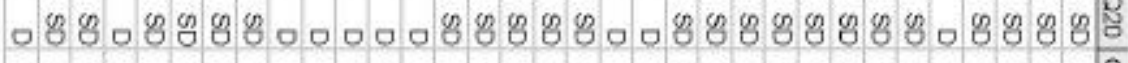

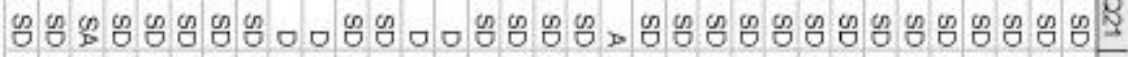

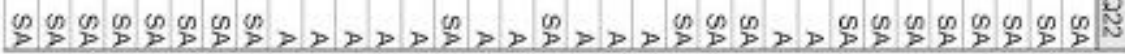




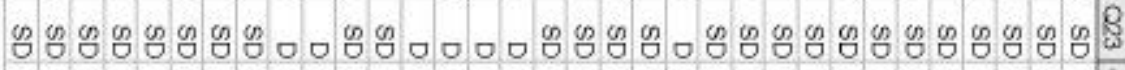

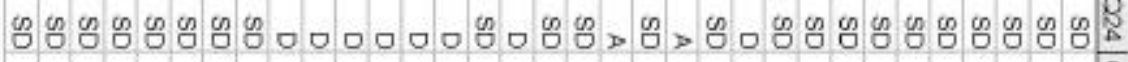

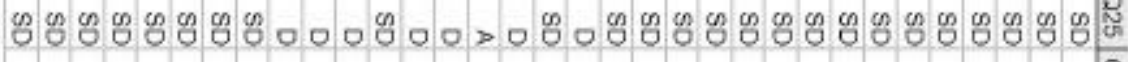

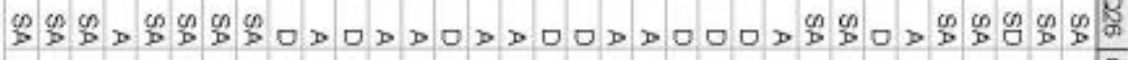

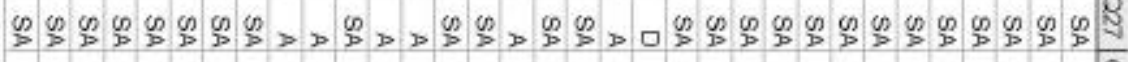

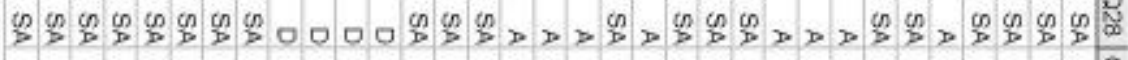

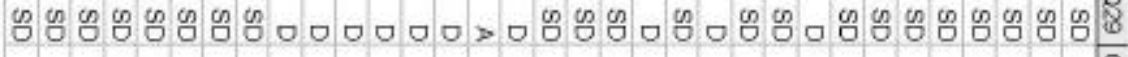

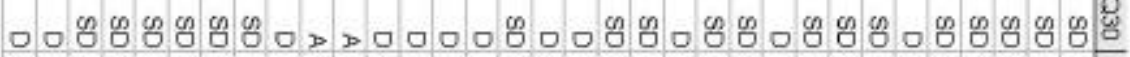
タ888в888

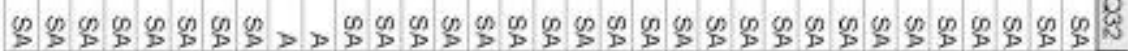

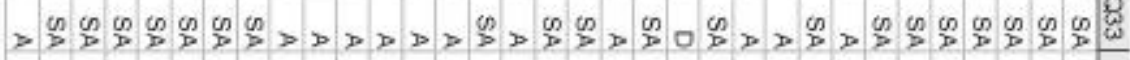
щ

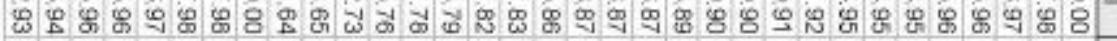

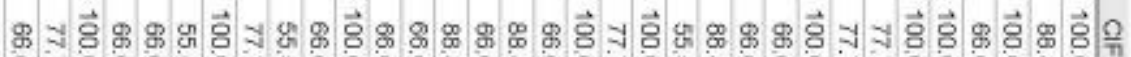
小

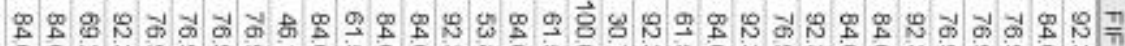

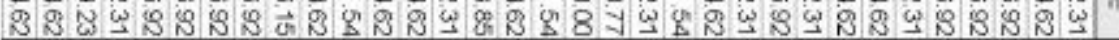




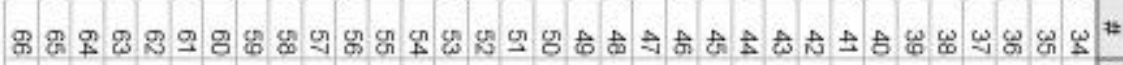

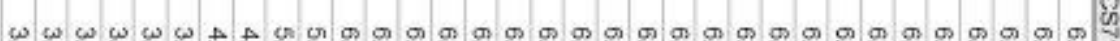
$888888888888888888888888888888888 \vec{N}$

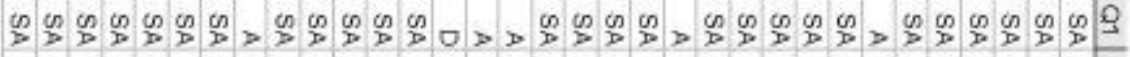

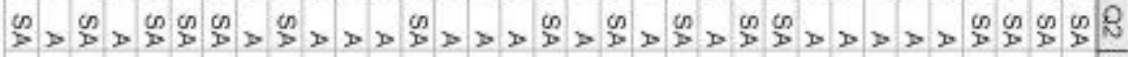

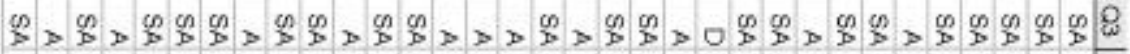

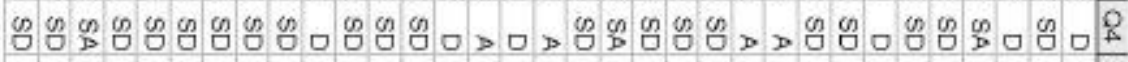

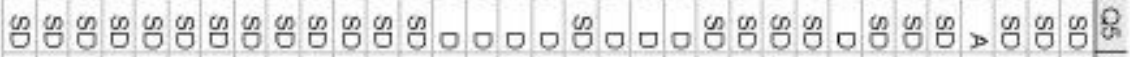

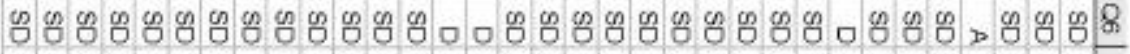

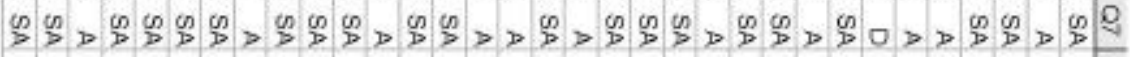

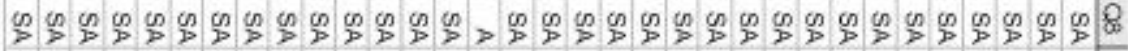

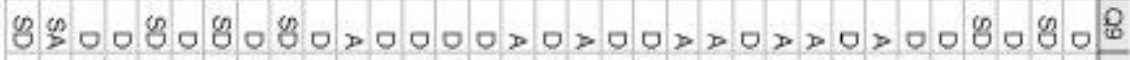

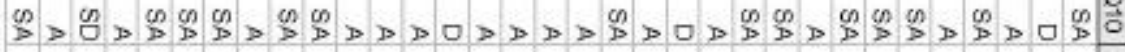

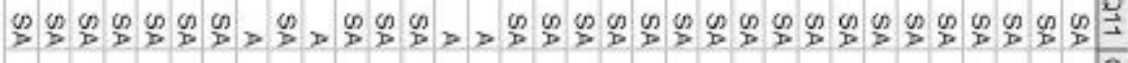

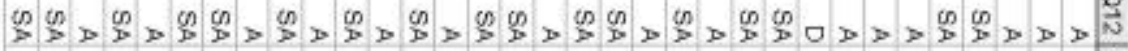

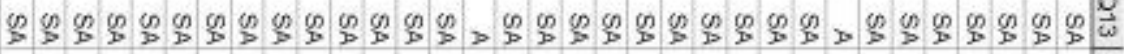

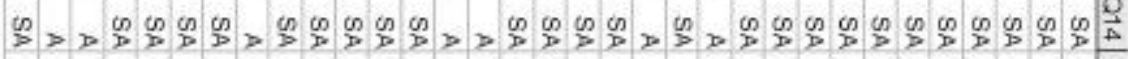

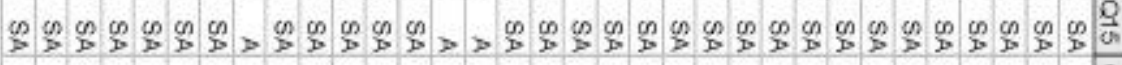

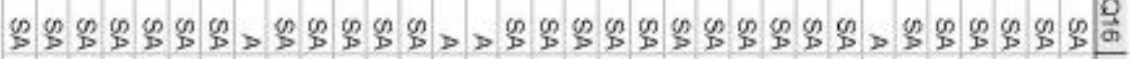

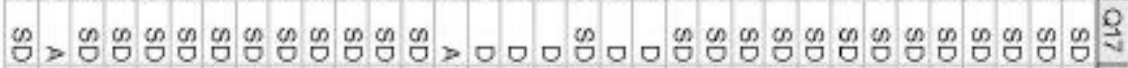

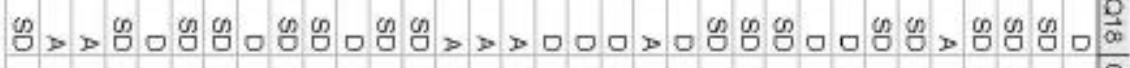

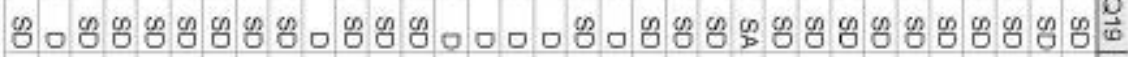
$8080888088888>00 \times 800088 \times 880888908$

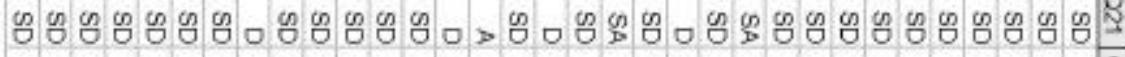

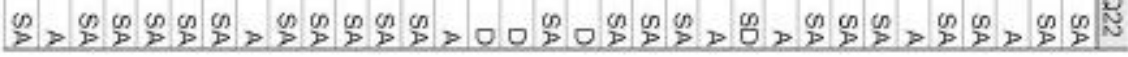




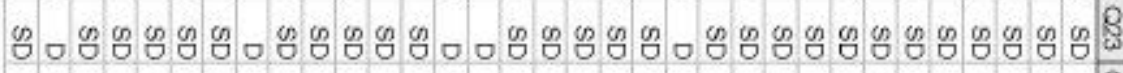

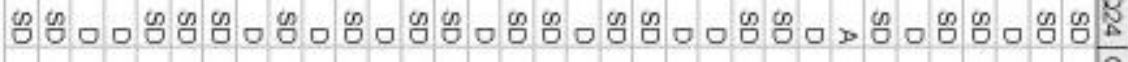

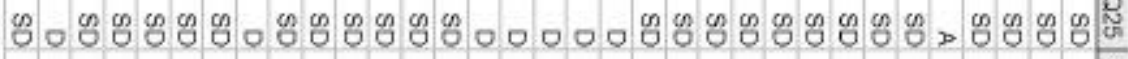

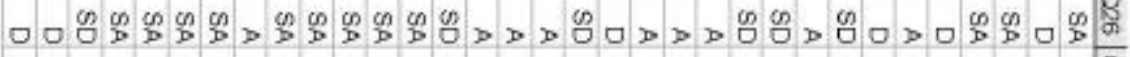

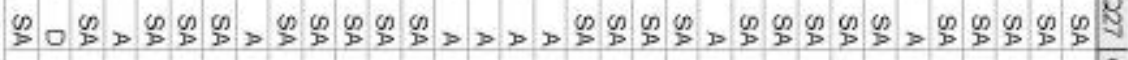

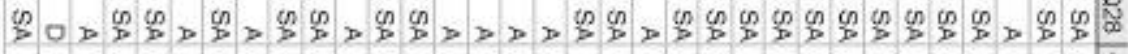

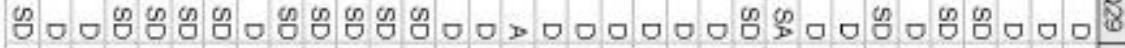

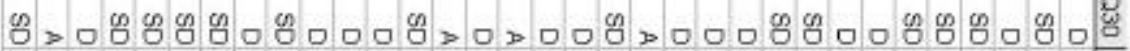

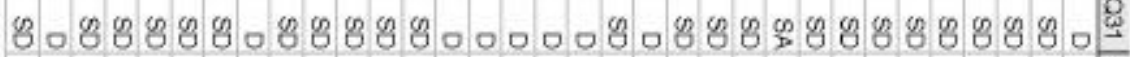

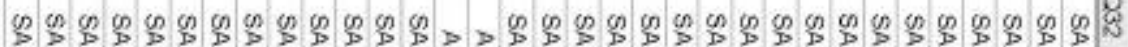

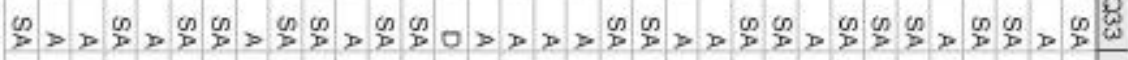

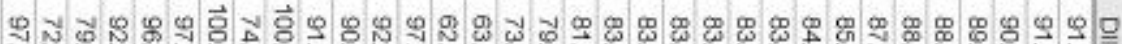

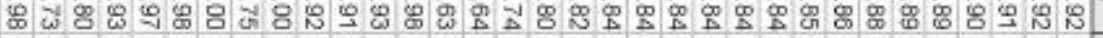

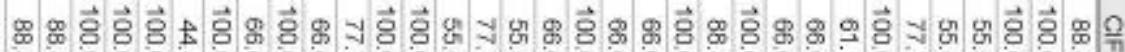

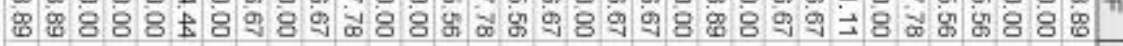

我

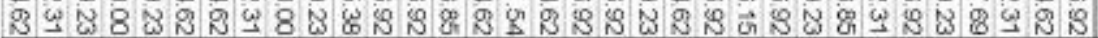




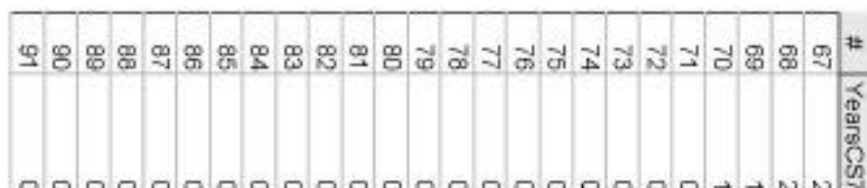

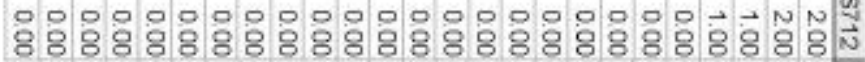

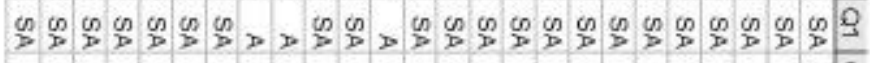

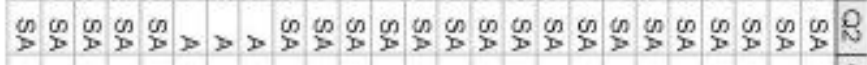

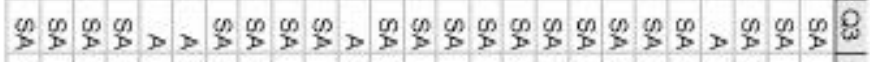

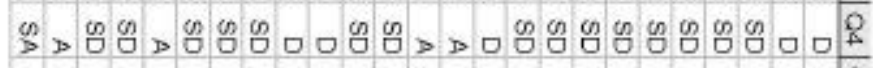

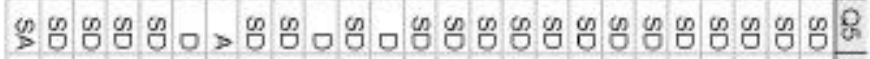

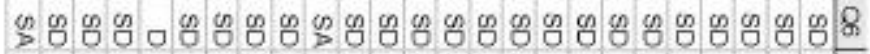

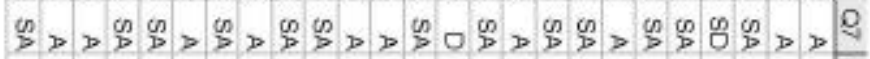

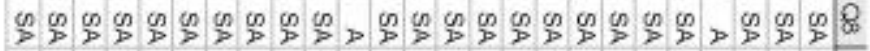

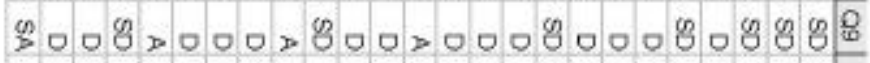

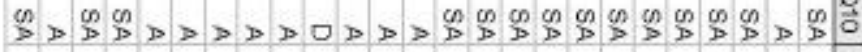

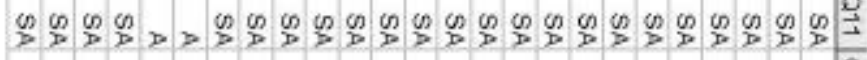

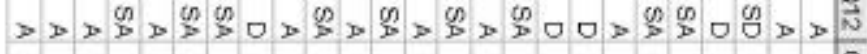

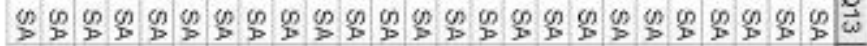

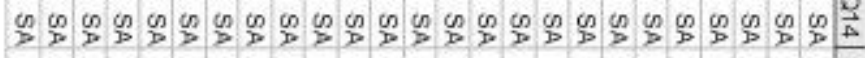

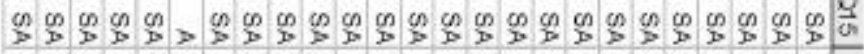

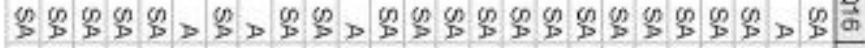

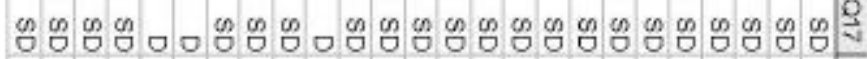

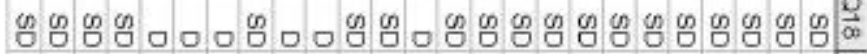

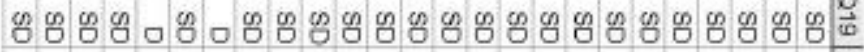

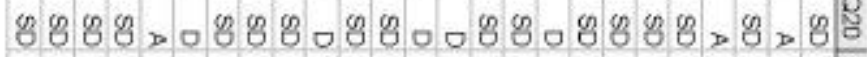

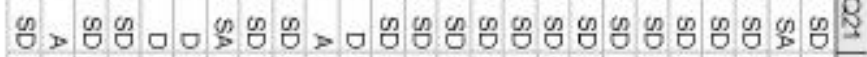

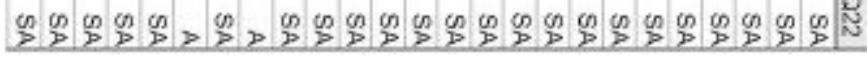




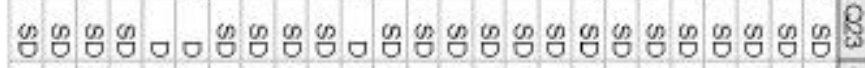

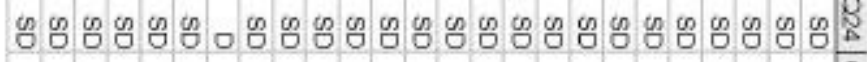

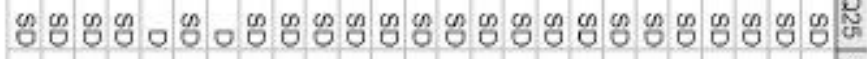

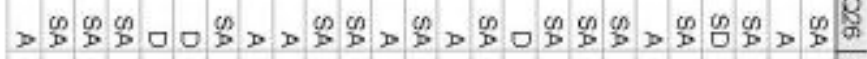

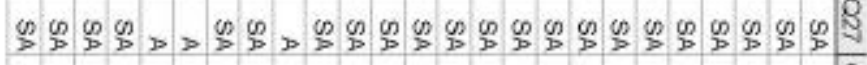

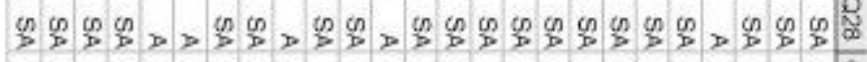

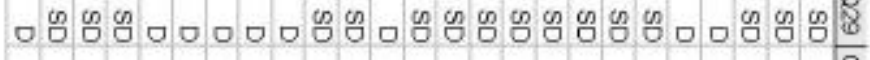

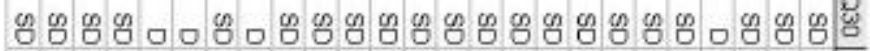

8988088808988888088888988

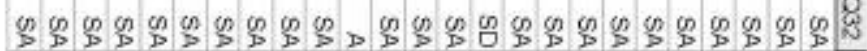

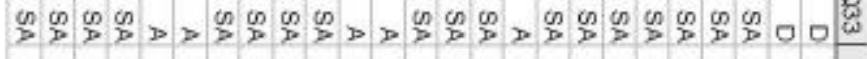

界 怘思穴

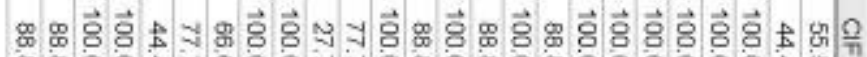
思88

خे

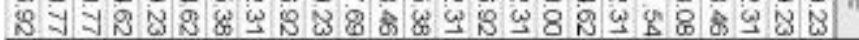




\section{REFERENCES}

Alma Heights Christian Academy. (2005). Mission statement. Retrieved December 10, 2005, from http://www.almaheights.org/about/mission.html

Anderson, W.T. (1990). Reality isn't what it used to be. San Francisco, CA: Harper \& Row.

Barna, G. (2001). Real teens. Ventura, CA: Regal Books / Gospel Light.

Beckwith, F.J. \& Koukl, G. (1998). Relativism: Feet firmly planted in mid-air. Grand Rapids, MI: Baker Books.

Bock, D.L. (2002). Purpose-directed theology: Getting our priorities right in evangelical controversies. Downer's Grove, IL: InterVarsity Press.

Brown, W.E. (2001). Where have all the dreamers gone. Dayton, TN: Bryan College Press.

Center for Disease Control. (2005). Suicide: Fact sheet. Retrieved November 27, 2005 from http://www.cdc.gov/ncipc/factsheets/suifacts.htm

Christian Unified Schools of San Diego. (2003). Mission statement. Retrieved December 10, 2005 from http://www.christianunified.com/generalinfo.htm 
Colson, C. (2000, August 7). Salad-bar Christianity. Christianity Today, 44, 80. Retrieved July 13, 2003 from http://www.christianitytoday.com/ct/2000/009/ 31.80.html

Colson, C., \& Pearcey, N. (1999). How now shall we live. Wheaton, IL: Tyndale House Publishers, Inc.

Dayton Christian Schools. (2005). Mission statement. Retrieved December 10, 2005 from http://www.daytonchristian.com/website/index.asp?webpageid=\{1FEF8304A187-4404-9D87-2C5BD817B58C $\}$

Dayton Christian schools faculty / staff handbook. (2000). Dayton, OH: Dayton Christian Schools, Inc.

Driscoll, M. (2000). Psychology of learning for instruction. Needham Heights, MA: Allyn \& Bacon.

Eagleton, T. (1996). The illusions of postmodernism. Cambridge, MA: Blackwell Publishers Inc.

Erickson, M.J. (1998). Postmodernizing the faith: Evangelical responses to the challenge of postmodernism. Grand Rapids, MI: Baker Books. 
Erickson, M.J. (2001). Truth or consequences: The promise \& perils of postmodernism. Downers Grove, IL: InterVarsity Press.

Erickson, M.J. (2002). The postmodern world: Discerning the times and the spirit of our age. Wheaton, IL: Crossway Books.

Feeney, J. (1997, November 15). Can a worldview be healed? Students and postmodernism. America, 177, 12-16. Retrieved June 20, 2005 from Academic Search Premier database.

Gangel, K. (2003). Biblical foundations of education. In J. Braley, J. Layman, \&R. White (Eds.), Foundations of Christian school education (p.53-66). Colorado Springs, CO: Purposeful Design Publications.

Gangné R.M. \& Glaser R. (1987). Foundations in learning research. Hillsdale, NJ: Erlbaum.

Grenz, S.J. (1996). A primer on postmodernism. Grand Rapids, MI: William B. Eerdmans Publishing.

Grudem, W. (1999). Bible doctrine: Essential teachings of the Christian faith. Grand Rapids, MI: Zondervan. 
Guiness, O. (2000). Time for truth: Living free in a world of lies, hype, \& spin. Grand Rapids, MI: Baker Books.

Heiman, G.W. (2001). Understanding research methods and statistics: An integrated introduction for psychology. Boston, MA: Houghton Mifflin.

Hellmich, N. (2002, July 16). Sedentary kids called to action in national campaign. USA Today retrieved July 15, 2003 from http://www.usatoday.com /news/health/child /2002-07-17-verb.htm

Horell, H.D. (2004). Fostering hope: Christian religious education in a postmodern age. Religious Education, 99, 5-22. Retrieved June 20, 2005 from Academic Search Premier database.

Kaiser Family Foundation. (November 1999). Kids \& media @ the new millennium. Fact sheet retrieved June 26, 2006 from http://www.kff.org/entmedia/loader.cfm? url=/commonspot/security/getfile.cfm\&PageID=13266

Kienel, P.A. (1995). Philosopy of Christian school education. In P.A. Kienel, O.E. Gibbs, \& S.R. Berry (eds.), Philosophy of Christian Education (p. i-xviii). Colorado Springs, CO: Association of Christian Schools International.

Kurtz, P. (2000). Humanist manifesto 2000. Amherst, NY: Prometheus Books. 
Kurtz, P. (Ed.). (1973). Humanist manifestos I and II. Amherst, NY: Prometheus Books.

Long, J. (2004). Emerging hope: A strategy for reaching postmodern generations. Downer's Grove, IL: InterVarsity Press.

MacArthur, J. (2002). Why one way? Defending an exclusive claim in an inclusive world. Nashville, TN: W Publishing Group.

Manning, B. (1990). The ragamuffin gospel. Sisters, OR: Multnomah Publishers, Inc.

McDowell, J. \& Hostetler B. (1998). The new tolerance: How a cultural movement threatens to destroy you, your faith, and your children. Wheaton, IL: Tyndale House Publishers.

McDowell, J. \& Hostetler B. (2002). Beyond belief to convictions. Wheaton, IL: Tyndale House Publishers.

McManus, E.R. (2001). An unstoppable force: Daring to become the church God had in mind. Orange. CA: Group Publishing.

Middleton, J.R. \& Walsh, B.J. (1995). Truth is stranger than it used to be: Biblical faith in a postmodern age. Downers Grove, IL: InterVarsity Press. 
Merriam-Webster's Collegiate Dictionary $\left(10^{\text {th }}\right.$ ed.). (1995). Springfield, MA: Merriam-Webster, Inc.

Moseley, N.A. (2003). Thinking against the grain: Developing a biblical worldview in a culture of myths. Grand Rapids, MI: Kregel Publications.

Nash, R.H. (1992). Worldviews in conflict: Choosing Christianity in a world of ideas. Grand Rapids, MI: Zondervan Publishing.

Oden, T.C. (1992). Two worlds: Notes on the death of modernity in America \& Russia. Downers Grove, IL: Inter-Varsity Press.

Payne, T. (1794). The age of reason being an investigation of true and fabulous theology. New York, NY: Willey.

Phillips, T. R. \& Okholm D.L. (2001). A family of faith: An introduction to evangelical Christianity. Grand Rapids, MI: Baker Academic.

Phillips T.R. \& Okholm D.L. (Eds.). (1995). Christian apologetics in the postmodern world. Downer's Grove, IL: InterVarsity Press. 
Raschke, C. (2004). The next reformation: Why evangelicals must embrace postmodernity. Grand Rapids, MI: Baker Academic.

Reid, T. (2003, April 18). Associated Press retrieved June 26, 2006 from http://www.cpyu.org/Page.aspx?id=77068

Sagan, C. (1980). Cosmos. New York, NY: Random House.

Schaeffer, F. (1981). A Christian manifesto. Wheaton, IL: Crossway Books.

Schindler, C.E. \& Pyle, P. (1997). Still education for eternity: The case for Christian schools. Whittier, CA: Association of Christian Schools International.

Schultz, G. (2002). Kingdom education: God's plan for educating future generations. Nashville, TN: LifeWay Press.

Spring, J. (2001). The American school: 1642-2000. New York, NY: McGraw-Hill

Thornhill, J. (2000). Modernity: Christianity's estranged child reconstructed. Grand Rapids, MI: William B. Eerdmans Publishing.

U.S. Department of Education, Office of the Secretary, Office of Public Affairs. (2003). No child left behind: A parent's guide. Washington, D.C. 
Veith, G.E. (1994). Postmodern times: A Christian guide to contemporary thought and culture. Wheaton, IL: Crossway Books.

Walsh, B.J., \& Middleton, J.R. (1984). The transforming vision: Shaping a Christian worldview. Downers Grove, IL: InterVarsity Press.

Youngblood, R.F. (Ed.). (1995). Nelson's new illustrated Bible dictionary. Nashville,TN: Thomas Nelson, Inc. 
VITA

David Hugh Bryant was born in Pompton Plains, New Jersey on June 6, 1966. He was raised in a Jewish home and had his Bar Mitzvah at age thirteen. Through the influence of two great friends, he was introduced to Jesus Christ and in September of 1988 he received salvation and gave Christ the Lordship of his life. The same two friends baptized David during November of that year in the chilly Pacific Ocean.

David graduated in 1984 from San Dieguito High School in Encinitas, California. Following graduation, he attended the University of California, San Diego, and was awarded his Bachelors of Arts in General Biology in 1989. Having been saved shortly before graduating, David prayerfully sought the Lord's direction in life and decided that it was teaching. In 1990 he completed an additional year of coursework in education at Christian Heritage College in El Cajon, California, earning his teaching credential.

David married his wife, Elicia, in December of 1989 and in 1991, she gave birth to their son, Nathan. As a family, they enjoy traveling, shooting, and exercising together. As of 2006, David has been a Christian schoolteacher for fourteen years, the last ten of which have been for Dayton Christian Schools in Dayton, Ohio. Since being with Dayton Christian, he's taught algebra and pre-algebra at the middle school, sixth grade Bible, math, and science at the Xenia Christian Campus, and for the 2006-2007 school year, he will be going to the Northwest Campus to teach biology, geometry, and sixth through eighth grade science.

David began taking classes at Cedarville University in the summer of 2000 and is excited to finally have completed his Master's Degree in Education. The program, he says, has been instrumental in making him a more effective and better teacher. 